\title{
A Single-Center Evaluation of Environmental Emissions from ENDS and Combustible Cigarettes *
}

\author{
by \\ John W. Caraway, $P h D^{1}$, Tao Jin, $M S^{2}$ Eckhardt Schmidt, $P h D^{2}$, and Paul R. Nelson, PhD ${ }^{2}$ \\ ${ }^{1}$ R.J. Reynolds Tobacco Company, 401 N. Main Street, Winston Salem, NC, USA \\ ${ }^{2}$ RAI Services Company, 401 N. Main Street, Winston Salem, NC, USA
}

\section{SUMMARY}

As the use of electronic nicotine delivery systems (ENDS) continues to increase, there is a need to evaluate their impact on indoor air quality. This study evaluated the differences in concentrations of volatile and particulate compounds (including formaldehyde, benzene, glycerol, propylene glycol, nicotine, and particulate matter) in secondhand vapor (SHV) after ad libitum subject vaping of cig-a-like ENDS, after-subject smoking of combustible cigarettes (CC), and after-subject non-smoking/non-vaping (blank) in an environmental test chamber. A single-center, open-label, parallel-group study was conducted. Seventyone generally healthy smokers and vapers were randomized to one of six cohorts: Marlboro Gold Pack, Newport Box, Vuse non-menthol (14 mg nicotine/cartridge and $29 \mathrm{mg}$ nicotine/cartridge), Vuse menthol (29 mg nicotine/cartridge), and market-sample ENDS. Concentrations of most secondhand constituents were similar after e-cigarette vaping and blank sessions. Constituent concentrations in SHV after ENDS use were significantly lower than in secondhand smoke (SHS) from CC, with the exception of glycerol and propylene glycol. Secondhand nicotine concentrations after ENDS use were 88-99\% lower than after cigarette smoking. Emission factors between the three Vuse products were also similar with the exception of propylene glycol. Concentrations of some secondhand constituents after ENDS use were compared to existing indoor and occupational air quality guidelines and did not show potential to contribute appreciably to indoor air quality. These findings indicate that SHV from ENDS differs qualitatively and quantitatively from the SHS from CC. [Contrib. Tob. Nicotine Res. 30 (2021) 3-24]
KEY WORDS:

Secondhand smoke; secondhand vapor; environmental tobacco smoke; ETS; vapor; electronic cigarette; electronic nicotine delivery system; ENDS

\section{ZUSAMMENFASSUNG}

Da die Nutzung von elektronischen Nikotinabgabesystemen (ENDS) weiter zunimmt, ist es nötig, deren Einfluss auf die Luftqualität in Innenräumen zu untersuchen. In dieser Studie wurden die Unterschiede in den Konzentrationen von flüchtigen Verbindungen und Partikelverbindungen (einschließlich Formaldehyd, Benzol, Glyzerin, Propylenglykol, Nikotin und Partikelmasse) im Passivdampf (secondhand vapor, SHV) nach dem Dampfen von zigarettenartigen ENDS (Zigalikes) ad libitum durch die Probanden, nach dem Rauchen von brennbaren Zigaretten (combustible cigarettes, $C C$ ) durch die Probanden und nach dem Nichtrauchen / Nichtdampfen (Blindversuch) durch die Probanden in einer Klimakammer untersucht. Es wurde eine monozentrische, offene Studie mit parallelen Gruppen durchgeführt. 71 Raucher und Dampfer in gutem allgemeinen Gesundheitszustand wurden randomisiert einer der folgenden sechs Kohorten zugeordnet: Marlboro Gold Pack, Newport Box, Vuse mentholfrei (14 mg Nikotin/ Kartusche und $29 \mathrm{mg}$ Nikotin/Kartusche), Vuse Menthol (29 mg Nikotin/Kartusche) sowie handelsübliche ENDS-Stichproben. Nach dem Dampfen der E-Zigarette und nach der Durchführung der Blindversuche waren die Konzentrationen der meisten Passivdampf-Bestandteile ähnlich. Die Bestandteilkonzentrationen im Passivdampf SHV nach 
dem Konsum von ENDS waren, mit Ausnahme von Glyzerin und Propylenglykol, signifikant geringer als diejenigen im Passivrauch (secondhand smoke, SHS) nach dem Konsum einer brennbaren Zigarette CC. Die Nikotinkonzentrationen nach Konsum von ENDS im Passivdampf waren um 88-99\% niedriger als die Konzentrationen nach dem Zigarettenrauchen. Die Emissionsfaktoren bei den drei Produkten von Vuse waren mit Ausnahme von Propylenglykol jeweils ähnlich. Die Konzentration einiger Bestandteile des Passivdampfs nach Konsum von ENDS wurde mit den geltenden Leitlinien zur Luftqualität in Innenräumen und am Arbeitsplatz abgeglichen, und es ergab sich hieraus kein nennenswerter potenzieller Beitrag dieser Bestandteile zur Raumluftqualität. Aus den Ergebnissen lässt sich schließen, dass sich der Passivdampf aus ENDS qualitativ und quantitativ vom Passivrauch aus brennbaren Zigaretten unterscheidet. [Contrib. Tob. Nicotine Res. 30 (2021) 3-24]

\section{RESUME}

Au vu de la progression continue de l'utilisation des dispositifs électroniques d'administration de nicotine (ENDS en anglais), le besoin apparaît d'évaluer leur impact sur la qualité de l'air à l'intérieur. La présente étude évalue les différences de concentrations de composés volatiles et de particules (y compris le formaldéhyde, le benzène, le glycérol, le propylène glycol, la nicotine et les particules) dans la vapeur secondaire (SHV en anglais) après le vapotage ad libitum par les sujets à l'aide d'un dispositif cigalike (petite cigarette électronique), après le fumage par les sujets de cigarettes combustibles (CC) et après le non-vapotage/non-fumage par les sujets (essai à blanc) dans une salle d'essais environnementaux. Une étude unicentrique, ouverte avec des groupes parallèles fut menée. Soixante-et-onze fumeurs et vapoteurs en bonne santé générale furent répartis aléatoirement dans une des six cohortes: Marlboro Gold Pack, Newport Box, Vuse non mentholée (14 mg de nicotine par cartouche et $29 \mathrm{mg}$ de nicotine par cartouche), Vuse mentholée (29 mg de nicotine par cartouche) et un échantillon d'ENDS prélevé sur le marché. A l'issue du vapotage d'une cigarette électronique et des sessions à blanc, les concentrations observées des principaux composés de la vapeur secondaire furent similaires. Les concentrations de composés dans la vapeur secondaire SHV relevées après l'utilisation de l'ENDS furent significativement inférieures aux valeurs de la fumée secondaire des $\mathrm{CC}$, à l'exception du glycérol et du propylène glycol. Les concentrations en nicotine dans la vapeur secondaire après utilisation de l'ENDS furent 88 à 99\% inférieures aux taux mesurés après le fumage de cigarettes. Les coefficients d'émission parmi les trois produits Vuse furent également similaires, à l'exception du coefficient relatif au propylène glycol. Les concentrations de certains composés de la vapeur secondaire après vapotage avec l'ENDS furent comparées aux lignes directrices applicables à la qualité de l'air à l'intérieur et en milieu professionnel et ne semblèrent pas pouvoir potentiellement apporter une contribution appréciable à la qualité de l'air à l'intérieur. Ces conclusions indiquent que la vapeur secondaire provenant des dispositifs électroniques d'administration de nicotine diffère en qualité et en quantité de la fumée secondaire libérée par les cigarettes combustibles. [Contrib. Tob. Nicotine Res. 30 (2021) 3-24]

\section{INTRODUCTION}

Environmental tobacco smoke (ETS) results from the combustion of tobacco cigarettes and is comprised of the mainstream smoke exhaled by smokers and the sidestream smoke emitted from the burning end of the cigarette itself (1). Electronic nicotine delivery systems (ENDS) are electronic devices that aerosolize a liquid which generally contains tobacco-derived nicotine and operate at much lower temperatures than combustible cigarettes (CC). ENDS are commonly comprised of a battery, heating element and, for some designs, a cartridge containing an e-liquid. This e-liquid typically consists of a mixture of propylene glycol, glycerol, nicotine, water, and flavorings $(3,4)$. Mainstream aerosol generated from ENDS and the aerosol exhaled by ENDS users (referred to hereafter as secondhand vapor (SHV)) compared to mainstream cigarette smoke and ETS, respectively, have been shown to contain far fewer known toxicants at much lower levels (5-12).

As ENDS use becomes more common in the US and abroad, there is a clear and increasing need to evaluate indoor air quality prior to, during, and after their use (13-16). Some studies have examined indoor air quality associated with SHV under real-world conditions or in an environment designed to mimic such conditions (17-24). A small study found that passive exposure to SHV led to nicotine absorption among people who did not smoke or vape (25). In this small study, a passive unvalidated sampling device was used. Another study measured volatile organic compounds (VOCs), polycyclic aromatic hydrocarbons (PAHs), tobacco-specific nitrosamines, and trace metal levels in the air before, during, and after ad libitum vaping of ENDS by human subjects in a naturally-ventilated office meeting room. Increases in a number of constituents were observed; however, most were well below current occupational air quality guidelines and current air quality regulatory standards (16). One small study also evaluated SHV from ENDS in a ventilated meeting room over the course of seven days. On the first day (control day), the air was monitored with no ENDS use and no subjects present in the room. Over the next six days, nine subjects consumed ENDS with and without nicotine in the same room for two hours. The authors found elevated levels of propylene glycol, glycerol, nicotine, particulate matter $\left(\mathrm{PM}_{2.5}\right)$, PAHs, and aluminum (26). However, the control did not include background analyte levels contributed by people. Further, no replicate runs were performed; consequently, it is difficult to determine the extent to which analytical variability impacted study results and conclusions. A more recent study examined exposure to carbon monoxide (CO) and particles in an unoccupied flat and a vehicle and found reductions in $\mathrm{CO}$, particulate matter, and black carbon exposure from two ENDS products relative to combustible cigarettes (24).

Two recent studies measured indoor air quality during ENDS conventions. One found high concentrations of $\mathrm{PM}_{2.5}$ in areas where ENDS use was permitted (2), while the other found similar concentrations of formaldehyde and acetaldehyde between control (crowd) and convention; exposure to nicotine and PG was also detected during events (27). Other researchers have reported on the SHV and third-hand (surface) exposure among three ENDS users 
and six non-ENDS users in a furnished room designed to resemble a social setting. Subjects completed two sessions conducted on separate days, involving 2-h ad libitum vaping of a disposable ENDS, and the second involving 2-h ad libitum vaping of a tank-style ENDS device. Measurements of $\mathrm{PM}_{2.5}$, ultrafine particles, air nicotine, and surface nicotine levels were significantly higher during both the disposable and tank sessions than measurements taken preand post-sessions (15).

Although investigations under real-world conditions are ideal, it is difficult to control for background sources of potential SHV constituents and therefore difficult to obtain accurate measurements. Furthermore, the extent of secondhand exposure to constituents in ENDS vapor depends on a number of factors, including the ventilation, room size, indoor climate, room furnishings, and number of ENDS in use (17). Studies conducted in environmental chambers allow for controlled generation and monitoring of vapor, and permit background concentrations of constituents to be reduced and reliably measured (28). One such study found VOC concentrations in chamber air to be much lower following the use of ENDS than after the use of CC (29). Another study found that ENDS were a source of passive exposure to nicotine; however, the average concentration of nicotine associated with smoking $\mathrm{CC}$ was 10 times higher than that associated with ENDS use. Furthermore, exposure to carbon monoxide (CO) and VOCs was in the same range for ENDS as the non-smoking test condition (20).

Two recent chamber studies utilized validated industrial hygiene sampling methodologies to estimate the risk of exposure to SHV among non-ENDS users. Analytes of interest across the studies included nicotine, menthol, propylene glycol, glycerol, total particulate matter (TPM), and formaldehyde. Both studies incorporated six 1-h vaping sessions held over the course of a 12-h day. Subjects vaped one of three prototype ENDS (menthol or non-menthol) according to specified puffing instructions. Upon analysis, results for all constituents at each sampling location for both studies were below the limit of quantitation, with the exception of formaldehyde. Elevated measures thereof were attributed to background formaldehyde emission from building components and existing formaldehyde in the indoor air supply (18). It is important to note, however, that these findings do not represent ad libitum use and therefore may not be generalizable to emissions generated by ENDS under normal conditions.

Another recent chamber study evaluated room air levels of nicotine, propylene glycol, glycerol, carbonyl chemicals, VOCs, and selected trace elements in a $114 \mathrm{~m}^{3}$ exposure chamber (30). Subjects vaped/smoked electronic vapor products (cig-a-likes and tanks) as well as CC. Background levels of constituents were measured both with and without subjects present in the chamber. In addition, both controlled and ad libitum vaping/smoking sessions were conducted. Nicotine, propylene glycol, and glycerol were significantly higher than baseline during all product uses and conditions, however concentrations were well below time-weighted average (TWA) limits from established workplace exposure. Of the remaining constituents, more than $75 \%$ were measured at or below the limit of quantification (LOQ) during vapor product use. During CC use, $50 \%$ of constituents were statistically significantly higher than baseline.
The goal of the present study was to increase understanding of the composition of SHV from ENDS, quantitatively compare the amount of SHV generated by Vuse ENDS and a market sample of commercial cig-a-like ENDS to leading brand styles of commercial $\mathrm{CC}$, and to quantitate the emission factors of the Vuse ENDS and market-sample ENDS. There is no validated standard methodology to determine SHV from ENDS use. In order to assess potential health risks from ENDS emissions, effective and reliable assessments of SHV constituents are needed. Some limitations among previous studies that examined the SHV generated by ENDS include: measurement of a limited number of smoke constituents; failure to perform replicate analysis (which precluded statistical comparison of results); or the work was carried out in poorly controlled environments (unknown ventilation rates) $(16,20,25,26)$. This study examined a broad range of SHV and secondhand smoke (SHS) constituents in a manner consistent with published methods for CC (31). A methodology to generate secondhand emissions at concentrations greatly exaggerated above "typical" concentrations (28) was used to ensure reliable quantitation of trace components, especially when the ENDS were tested. Additionally, determination of secondhand ENDS emissions was performed using analytical methods validated according to applicable Good Laboratory Practices to ensure consistency and reliability of the results.

\section{METHODS}

\section{Study products}

Three Vuse ENDS products consisting of a battery, sensor, and microchips, as well as a cartridge containing propylene glycol, glycerol, nicotine, flavorings, and water were evaluated in this study. Two of the products were Vuse Solo Original and contained 14 and $29 \mathrm{mg}$ of nicotine per cartridge, respectively. The third was Vuse Solo Menthol and contained $29 \mathrm{mg}$ of nicotine per cartridge. Two commercially available cigarette products (Marlboro Gold Pack Box, Newport Box) were also evaluated. These products were chosen because each is the leading cigarette brand style in its respective market segment (i.e., non-menthol and menthol). Finally, two ENDS brands (blu $\left.{ }^{\mathrm{TM}}, \mathrm{NJOY}^{\circledR}\right)$ were chosen to represent cig-a-like products as they accounted for approximately $60 \%$ of the market at the time of study conduct (32). Any commercially available blu ${ }^{\mathrm{TM}}$ and NJOY ${ }^{\circledR}$ product and flavor were allowed for evaluation during the study.

\section{Study design}

This was a single-center, open-label, parallel-group study designed to measure the differences in levels of SHV constituents, including volatile organic compounds (VOCs) (Table 1), after ad libitum subject vaping of ENDS in an environmental test chamber. The compounds in Table 1 were chosen based on FDA's list of harmful and potentially harmful constituents (HPHCs), FDA's concern that some of these constituents could potentially cause health hazards, and published articles on secondhand smoke (33). 
Table 1. Secondhand vapor/secondhand smoke constituents measured during environmental chamber test sessions.

\begin{tabular}{|c|c|}
\hline SHVISHS constituents & $\begin{array}{l}\text { Lower limit of } \\
\text { quantification }\end{array}$ \\
\hline Acetaldehyde & $2.0 \mu \mathrm{g} / \mathrm{m}^{3}$ \\
\hline Ammonia $\left(\mathrm{NH}_{3}\right)$ & $67.0 \mu \mathrm{g} / \mathrm{m}^{3}$ \\
\hline Benzene & $0.4 \mu \mathrm{g} / \mathrm{m}^{3}$ \\
\hline Carbon monoxide (CO) & $0.1 \mathrm{mg} / \mathrm{m}^{3}$ \\
\hline Cresol & $0.1 \mu \mathrm{g} / \mathrm{m}^{3}$ \\
\hline Ethylbenzene & $0.1 \mu \mathrm{g} / \mathrm{m}^{3}$ \\
\hline Fluorescent particulate matter (FPM) & $1.0 \mu \mathrm{g} / \mathrm{m}^{3}$ \\
\hline Formaldehyde & $2.0 \mu \mathrm{g} / \mathrm{m}^{3}$ \\
\hline Glycerol & $8.3 \mu \mathrm{g} / \mathrm{m}^{3}$ \\
\hline Hydroquinone & $0.8 \mu \mathrm{g} / \mathrm{m}^{3}$ \\
\hline Nicotine & $0.2 \mu \mathrm{g} / \mathrm{m}^{3}$ \\
\hline Phenol & $0.4 \mu \mathrm{g} / \mathrm{m}^{3}$ \\
\hline Propylene glycol & $2.0 \mu \mathrm{g} / \mathrm{m}^{3}$ \\
\hline Pyridine & $0.1 \mu \mathrm{g} / \mathrm{m}^{3}$ \\
\hline Pyrrole & $0.1 \mu \mathrm{g} / \mathrm{m}^{3}$ \\
\hline Respirable suspended particles (RSP) $\left(\mathrm{PMR}_{2.5}\right)$ & $2.0 \mu \mathrm{g} / \mathrm{m}^{3}$ \\
\hline Solanesol & $0.3 \mu \mathrm{g} / \mathrm{m}^{3}$ \\
\hline Styrene & $0.1 \mu \mathrm{g} / \mathrm{m}^{3}$ \\
\hline Toluene & $0.4 \mu \mathrm{g} / \mathrm{m}^{3}$ \\
\hline Total volatile organic compounds (TVOC) & $11.5 \mu \mathrm{g} / \mathrm{m}^{3}$ \\
\hline Ultraviolet particulate matter (UVPM) & $1.0 \mu \mathrm{g} / \mathrm{m}^{3}$ \\
\hline Xylene & $0.1 \mu \mathrm{g} / \mathrm{m}^{3}$ \\
\hline
\end{tabular}

SHS = secondhand smoke

$\mathrm{SHV}=$ secondhand vapor

Results were compared both to after-subject smoking of $\mathrm{CC}$, and to a non-smoking/non-vaping blank condition. Emission factors were also determined for each ENDS and $\mathrm{CC}$ product. The methodology employed in this study was largely based on previous studies that utilized chamber sampling to measure secondhand emissions from CC $(28,31)$. All subjects provided written informed consent, and the study was approved by MidLands Institutional Review Board (IRB) (Overland Park, KS, USA). Male and female ENDS users (for ENDS cohorts) and smokers (for cigarette smoking cohorts) age 21 years and older were recruited from Stockbridge, GA and the surrounding area, including Atlanta, GA. This study consisted of an enrollment visit, a product-distribution visit, and a total of 10 chamber visits held at the study site. The study took place between May 21, 2014 and December 12, 2014.

The enrollment target for this study was 72 subjects, assigned to 1 of 6 cohorts (12 subjects per cohort) based on their current usual brand (UB) preference: Marlboro Gold Pack Box [Cohort 1]; Newport Box [Cohort 2]; menthol ENDS consumers willing to switch to a different menthol ENDS brand during study (Vuse menthol ENDS (29 mg nicotine/cartridge) [Cohort 3]); current non-menthol ENDS consumers willing to switch to a different non-menthol ENDS brand during study (Vuse non-menthol ENDS (29 mg nicotine/cartridge) [Cohort 4]); current non-menthol ENDS consumers willing to switch to a different nonmenthol ENDS brand during study (Vuse non-menthol ENDS (14 mg nicotine/cartridge) [Cohort 5]); or market sample ENDS consumers (blu ${ }^{\mathrm{TM}}$ or $\mathrm{NJOY}^{\circledR}$ [Cohort 6]). Investigational products were supplied to study subjects in
Cohorts 3, 4, and 5. Subjects in Cohorts 1, 2, and 6 were responsible for providing their own UB cigarettes or ENDS. Subjects in the Vuse cohorts were instructed to completely substitute the Vuse products for their regular ENDS product and to use their assigned products ad libitum during the 2 weeks prior to their chamber visits. This was done to ensure that the subjects were fully acclimated to the test product and their product use behavior in the chamber test sessions would represent that of experienced users of the product.

All subjects within a cohort were scheduled for the same chamber visit. Separate randomization lists were generated for each chamber visit test session and contained subject numbers for all subjects within a cohort. The first four subjects within a cohort who were identified on the randomization list and who were present participated in a test session. This process was used to minimize subject allocation bias for the chamber visit test sessions and to ensure timely conduct of the chamber visit test sessions if a subject arrived late to the testing site or failed to return for a chamber visit.

\section{Environmental test chamber}

Secondhand vapor and secondhand smoke emissions were measured in a $3.04 \mathrm{~m} \times 3.04 \mathrm{~m} \times 3.04 \mathrm{~m}$ (approximately $28.3 \mathrm{~m}^{3}$ ) emission chamber equipped with twin banks of overhead light-emitting diode (LED) lights and four 6" box fans mounted on the ceiling which ran throughout the test session to ensure mixing of the air within the chamber. The chamber was manufactured from stainless steel with polished interior walls and was devoid of furnishings to minimize sink effects from surface adsorption of SHV and SHS constituents. A $3.04 \mathrm{~m} \times 3.04 \mathrm{~m}$ wall panel, constructed of aluminum box cross members faced with polymer panels, covered the chamber opening. Panels were covered with an interior facing skin of polished stainless steel. A large glass viewing window mounted in the center of the panel allowed for viewing the chamber interior, and a hinged entrance door allowed ingress and egress to the chamber. A louvered vent, housing an activated charcoal filter, was mounted over the door. The vent was closed during chamber operation and was opened during chamber purges with High Efficiency-Particulate Air (HEPA)-filtered air. A schematic of the environmental chamber can be found in Additional Figure A1. Chamber conditions were set daily for static mode operation and were maintained at $25 \pm 1{ }^{\circ} \mathrm{C}$ and relative humidity $(\mathrm{RH})$ at $50 \pm 2 \%$ during each chamber run (smoking/vaping and blank). The air exchange rate during a chamber test session was determined from the change in carbon dioxide $\left(\mathrm{CO}_{2}\right)$ concentration over time. A stainless-steel manifold in a corner of the chamber held sample collection devices and was attached via tubes to sampling pumps outside the chamber. Tubes were precalibrated and synchronized via digital timer to open or close simultaneously at the sampling start and end times.

\section{Chamber visits}

The chamber visits for each cohort occurred over 2 weeks beginning with chamber visits 1 through 5 , which occurred during the first week, and continuing with chamber visits 6 
through 10, which occurred during the subsequent week. Chamber visits included five sessions in which four subjects smoked/vaped while in the environmental test chamber (smoking runs) and five sessions in which subjects did not smoke/vape while inside the environmental test chamber (blank runs). Each subject provided or received one UB cigarette, one Vuse investigational product cartridge and battery, or one UB ENDS (depending on the subject's cohort) for use during a test session. Butane lighters and ashtrays were provided to each subject in Cohorts 1 and 2 prior to entering the chamber for smoking runs. During a test session, the environmental test chamber was operated in static mode with the outside air and exhaust air dampers closed to allow for maximum collection of SHV and SHS. Subjects entered the test chamber (with their cigarette or ENDS for smoking runs), the test chamber entry was closed, and collection of real-time measurements of the test chamber atmosphere began. Subjects were continuously monitored for the $20 \mathrm{~min}$ they were in the chamber.

For smoking/vaping sessions, subjects were signaled $10 \mathrm{~min}$ after the start of the session and instructed to smoke/vape ad libitum. On days when smoking/vaping was not scheduled (blank runs), subjects remained in the environmental test chamber for 20 min without using product. At $19 \mathrm{~min}$ after the start of the session, subjects were signaled to indicate that it was almost time to exit the chamber; at $20 \mathrm{~min}$, the staff monitoring the test opened the door and subjects quickly exited the test chamber (with the lighters and ashtrays [smoking runs only for Cohorts 1 and 2]). Subjects in Cohorts 3, 4, and 5 returned their used investigational product to the study staff upon exit. The test chamber entry was closed, and collection of TWA samples of the test chamber atmosphere began. Time-weighted average samples were collected over a 2 -h period beginning $20 \mathrm{~min}$ after the start of the real-time data collection to determine concentrations of analytes in the chamber air, generated by subjects, and generated by products during the test runs and determination of concentration of analytes in chamber air and generated by subjects during the blank runs (the average difference being the amount of analyte generated by products).

\section{Analytical measurements}

The analysis of SHV and SHS constituents was performed by Materials Analytical Services, LLC (MAS) (Suwanee, GA, USA). The assays were validated according to applicable Good Laboratory Practices requirements and in compliance with Standard Operating Procedures (SOPs) in effect in the laboratory of MAS. The SOPs were based on the principles and requirements described in UNITED STATES FoOd AND DRUG ADMINISTRATION Title 21 Code of Federal Regulations (CFR) Part 58, as well as the Center for Drug Evaluation and Research's (CDER) Guidance for Industry - Bioanalytical Method Validation and the EUROPEAN MEDICINES AGENCY's Guideline on Bioanalytical Method Validation that were in place at the time the validation took place $(34,35)$. These methods included a combination of real-time sample collection and TWA samples collected and analyzed by the appropriate analytical techniques. Along with the SHV/SHS constituents listed in Table 1, temperature (T), $\mathrm{RH}$ and $\mathrm{CO}_{2}$ concentrations were measured for each run. A typical figure of the realtime measurements can be found in Additional Figure A2. Real-time measurement of total volatile organic compounds (TVOC), $\mathrm{CO}, \mathrm{CO}_{2}$, temperature, and $\mathrm{RH}$ was performed during all sessions using a WolfSense IQ-610 environmental probe (Graywolf ${ }^{\mathbb{B}}$ Sensing Solutions, Shelton, CT, USA), which used an electrochemical sensor for detection of $\mathrm{CO}$, a dual-wavelength non-dispersive infrared sensor for $\mathrm{CO}_{2}$, and a photoionization detector with a krypton $10.6 \mathrm{eV}$ ultraviolet (UV) emission source sensor for TVOC. The instrument sampled air through a port in the wall of the chamber and was started at the beginning of each test and allowed to operate and collect data during the entire test run. Sampling rate was one sample per $10 \mathrm{~s}$ for $140 \mathrm{~min}$. Duplicate samples were obtained from each test run to measure benzene, toluene, styrene, ethylbenzene, $o-, m-, p$ xylene, pyridine, pyrrole, $o-, m-, p$ - cresol, phenol, glycerol, and propylene glycol were obtained in accordance to US EPA method TO-17 (36) by air sampling through TENAX TA tubes at a flow rate of $0.05 \mathrm{~L} / \mathrm{min}$ for $120 \mathrm{~min}$ for CC and at rates of $0.05 \mathrm{~L} / \mathrm{min}$ for $120 \mathrm{~min}$ and $0.2 \mathrm{~L} / \mathrm{min}$ for $120 \mathrm{~min}$ for ENDS. For ENDS, TENAX tubes sampled at the appropriate flow rate were selected in order to stay within the calibration range for the analytes. The TENAX tubes were thermally desorbed, and the compounds of interest were separated by gas chromatography (GC) and then identified and quantified by mass spectrometry (MS) (Agilent 6890N GC; Agilent 5973N; Santa Clara, CA, USA).

Duplicate samples for formaldehyde and acetaldehyde were captured during each test run in accordance to NIOSH method 2016 (37) using silica-DNPH (2,4-dinitrophenylhydrazine) cartridges (Waters Sep-Pak ${ }^{\circledR}$ DNPH-Silica cartridges; WAT047205; Waters Corporation, Milford, MA, USA) at a flow rate of $1.5 \mathrm{~L} / \mathrm{min}$ for $120 \mathrm{~min}$. The extracts were stored in a freezer until analysis with HPLC (high-pressure liquid chromatography) (Model LC-10AT, Shimadzu Corporation, Kyoto, Japan) with a UV detector (Model SPD-10A, Shimadzu) at $365 \mathrm{~nm}$.

Duplicate ammonia samples were collected during each test run according to NIOSH method 6016 (38) by air sampling through sulfuric acid-treated silica gel tubes (SKC 226-1003; SKC, Inc., Eighty Four, PA, USA) at a flow rate of $0.5 \mathrm{~L} / \mathrm{min}$ for $120 \mathrm{~min}$. Each tube was placed into a small centrifuge tube, and $10 \mathrm{~mL}$ of deionized water was added. The tubes were then agitated and allowed to extract for $45 \mathrm{~min}$ at room temperature. Sample tubes from the chamber runs were stored for 1 week at room temperature, until analysis by ion chromatography (Dionex DX-1100, Thermo Fisher Scientific, Waltham, MA, USA).

Duplicate samples of hydroquinone were collected and analyzed from each test run according to OSHA method PV2094 (39). Samples were recovered from the front and back portions of the OVS XAD-7 sorbent media tubes (SKC, Inc.), extracted with $\mathrm{H}_{3} \mathrm{PO}_{4}$-acidified methanol for $30 \mathrm{~min}$ at room temperature. The extracts from both sections were then analyzed by GC and flame ionization detection (Agilent 5890 + Dual Detector SVOA System, Agilent).

Nicotine samples were collected in duplicate during each test run on XAD-4 sorbent tubes according to CORESTA Recommended Method No. 50 (40). The compound was 
desorbed using ethyl acetate and triethylamine for $60 \mathrm{~min}$ at room temperature. The extracts from both sections were then analyzed by GC using a nitrogen phosphorus detector (Agilent 6890N GC with 5973N Model \#G1530N, Agilent).

Five replicate samples for gravimetric respirable suspended particles (RSP) were collected and analyzed during each test run according to NIOSH 0501 (41), with filter type modified from polyvinyl chloride (PVC) to polytetrafluoroethylene (PTFE) for improved solvent resistance. Samples were collected on pre-weighed $37 \mathrm{~mm}$ diameter $1.0 \mu \mathrm{m}$ pore size PTFE filters housed in five inertial impactor cassettes (Cat. No. 225-2705, 225-352; SKC, Inc.). For sample collection, a known volume of air $(360 \mathrm{~L})$ was drawn through all impactors during each sampling session. The impactors separated RSP measuring 1.0-4.0 $\mu \mathrm{m}$ (impactor cut point $2.5 \mu \mathrm{m}$ ) and smaller from the total suspended particulate matter. After sample collection, the PTFE filters were stored in sealed vials in a freezer (below $0{ }^{\circ} \mathrm{C}$ ) until analysis. Following each test session, RSP on PTFE filters were retrieved from the sample cassette and re-weighed three times within $15 \mathrm{~min}$ on an analytical microbalance capable of $\geq 1.0 \mu \mathrm{g}$ accuracy (Cahn C-35, Thermo Fisher Scientific); the average mass of the RSP was then determined. Two of the five PTFE filters containing RSP were extracted using $3.00 \mathrm{~mL}$ methanol for $60 \mathrm{~min}$ at room temperature.

Analysis of solanesol was performed according to CORESTA Recommended Method No. 52 (42) by HPLC (Model LC-10AT, Shimadzu). Ultraviolet particulate matter (UVPM) and fluorescent particulate matter (FPM) were analyzed according to CORESTA Recommended Method No. 51 (43) by HPLC with UV (Model SPD-10A, Shimadzu) and fluorescence detection (Model FL3000, Thermo Fisher Scientific).

\section{Statistical analyses}

Air exchange rate was determined from the decay of $\mathrm{CO}_{2}$ measured in real-time in the chamber. Simple regression analysis was used to calculate decay rate for each session. Calculations of SHS analyte concentrations were based on TWA samples and background-corrected real-time data collected over specified testing periods. Background correction of real-time data was carried out by subtracting from measured data the average of the real-time data collected during a pre-defined period after the start of the chamber session ( $10 \mathrm{~min}$ ), to eliminate background concentrations in the chamber atmosphere before product use. Values below the lower limit of quantification (LLOQ) were imputed as LLOQ for calculation. Emission factors were then determined for each analyte and reported for those analytes that were statistically significantly above the blank. Two-sample 2-tailed $t$-tests were performed on derived endpoints to determine if there were differences between TWA concentrations for product and reference, and TWA concentrations for smoking/vaping and blank runs. Comparisons for all measured SHV and SHS constituents (primary and secondary objectives) were made at a 0.05 level of significance.

\section{Emission factors}

Emission factors were calculated for each analyte for each investigational product with respect to per-product use and with respect to "per-mg e-liquid" used for Vuse (Cohorts 3, 4, and 5). For TWA analytes, blank-corrected (BC subscript in equations) concentrations were used for the emission factor calculations. Emission factors were calculated as:

a. With respect to per-product (for all cohorts):

$$
\begin{aligned}
& \left(T W A_{B C} \frac{\mu g}{m^{3}}\right) \times\left(28.3 m^{3}\right) \times\left(\frac{P e a k}{T W A}\right) \times \\
& \frac{1}{\# \text { products }} \times \frac{m g}{1000 \mu g} \times \frac{m g}{\# \text { products }}
\end{aligned}
$$

b. With respect to "per-mg of e-liquid" used (for Cohorts 3,4 , and 5):

$$
\begin{aligned}
& \left(T W A_{B C} \frac{\mu g}{m^{3}}\right) \times\left(28.3 m^{3}\right) \times\left(\frac{P e a k}{T W A}\right) \times \\
& \frac{1}{m g \text { of } e-\text { liquid }} \times \frac{m g}{1000 \mu g} \times \frac{m g}{m g \text { of } e-\text { liquid }}
\end{aligned}
$$

To adjust for decay of analytes in the chamber due to air infiltration resulting from the sampling process and low levels of air infiltration (the chamber could not be completely sealed), the emission rates were corrected based upon the ratio of peak concentration to TWA concentration of $\mathrm{CO}_{2}$ in the chamber.

For real-time analytes, the emission factors were calculated directly from the background-corrected and blank-corrected peak concentration $\left(\mathrm{PEAK}_{\mathrm{BGBC}}\right)$. For TVOC, the calculation was:

a. With respect to per-product (for all Cohorts):

$$
\operatorname{PEAK}_{B G B C} \frac{\mu g}{m^{3}} \times\left(28.3 m^{3}\right) \times \frac{1}{\# \text { products }} \times \frac{m g}{1000 \mu g}=\frac{m g}{\# \text { products }}
$$

b. With respect to "per-mg of e-liquid" used (for Cohorts 3,4 , and 5):

$$
\begin{aligned}
& P_{B A K_{B G C} \frac{\mu g}{m^{3}} \times\left(28.3 m^{3}\right) \times} \\
& \frac{1}{m g \text { of } e-\text { liquid }} \times \frac{m g}{1000 \mu g}=\frac{m g}{m g \text { of } e-\text { liquid }}
\end{aligned}
$$

For $\mathrm{CO}$, the calculation was:

a. With respect to per-product (for all cohorts):

$$
P E A K_{B G B C} \frac{m g}{m^{3}} \times\left(28.3 m^{3}\right) \times \frac{1}{\# \text { products }}=\frac{m g}{\# \text { products }}
$$


b. With respect to "per mg of e-liquid" used (for Cohorts 3, 4, and 5):

$$
\begin{aligned}
& P E A K_{B G B C} \frac{m g}{m^{3}} \times\left(28.3 m^{3}\right) \\
& \times \frac{1}{m g \text { of } e-\text { liquid }}=\frac{m g}{m g \text { of } e-\text { liquid }}
\end{aligned}
$$

\section{RESULTS}

\section{Demographics}

A total of 71 subjects (12 in each of the Marlboro Gold Pack, Newport Box, Vuse non-menthol (14 mg nicotine/cartridge), Vuse non-menthol (29 mg nicotine/cartridge), and Vuse menthol (29 mg nicotine/cartridge) groups, and 11 in the market-sample ENDS group) were enrolled in the study. The mean ( \pm standard deviation (SD)) age of subjects was $34 \pm 9$ years. Subjects were mostly Black or African American (64.8\%) and White (32.4\%); and $97.2 \%$ of subjects were not Hispanic or Latino. Gender distribution was similar for males (49.3\%) and females (50.7\%). Among the 24 subjects enrolled in the Marlboro Gold Pack and Newport Box groups, the average $( \pm \mathrm{SD})$ self-reported number of cigarettes smoked per day was $15.1 \pm 6.2$; and two subjects were also dual users of ENDS. Subjects enrolled in the ENDS groups $(n=47)$ used an average $( \pm \mathrm{SD})$ of $2.68 \pm 2.2$ ENDS per week; and 27 reported ongoing daily or weekly cigarette smoking of $3.9 \pm 4.6$ cigarettes per day.

\section{Chamber conditions}

Average chamber conditions (air changes per h $(\mathrm{ACH}), \mathrm{T}$, and $\mathrm{RH}$ ) during smoking/vaping runs were consistent across all six cohorts and comparable to the values from all blank runs. Mean $\mathrm{ACH}$ values ranged from 0.06 to 0.10 for smoking/vaping runs and 0.07 to 0.10 for blank runs.

\section{Constituent analyses}

Average blank-corrected constituent concentrations by cohort are presented in Table 2. Uncorrected mean chamber concentrations are summarized in Additional Table A1. Statistical comparisons were made between uncorrected chamber concentrations of secondhand constituents from a product and its respective blank, and the results are presented in Additional Table A2. Notations were made in Table 2 where uncorrected secondhand constituent emissions from a product were statistically significantly different than from its respective blank. In general, mean uncorrected TWA concentrations of secondhand constituents from an ENDS were not statistically significantly different than from its respective blank. Exceptions were observed for nicotine emissions from each ENDS, for glycerol and propylene glycol emissions from both Vuse Menthol and Vuse non-menthol (29 mg nicotine/cartridge), and for ammonia emissions from Vuse non-menthol $(29 \mathrm{mg}$ nicotine/cartridge). For each of these exceptions, secondhand constituent concentration from the ENDS was statistically significantly higher than from its respective blank. Mean uncorrected TWA chamber concentrations of SHS constituents from the $\mathrm{CC}$ products were higher than from their respective blanks, and most differences were statistically significant $(\mathrm{p}<0.05)$ (Additional Tables A1 and A2). The only exception to these findings was glycerol, for which the difference between smoking and blank runs was not statistically significant.

The results of the statistical comparison ( $p$-values) of mean $\mathrm{TWA}_{\mathrm{BC}}\left(\mathrm{TWA}_{\mathrm{BGBC}}\right.$ for $\mathrm{CO}$ and TVOC) concentrations from the ENDS and their respective reference $\mathrm{CC}$ are summarized in Table 3. Comparisons in Table 3 are like-to-like; i.e., menthol products were compared to menthol products and non-menthol products were compared to non-menthol products. Because the market sample contained menthol and non-menthol products results were compared to both reference CCs.

For the majority of the SHV and SHS constituents evaluated in this study, mean $\mathrm{TWA}_{\mathrm{BC}}$ concentrations from ENDS were statistically significantly lower than $C C(p<0.05)$, with many of the chamber concentrations after ENDS vaping close to 0 or negative. Two exceptions were glycerol and propylene glycol. Glycerol levels following the marketsample ENDS and Vuse non-menthol (14 mg nicotine/ cartridge) vaping runs were higher than following CC smoking runs but were not statistically significant. When compared to $\mathrm{CC}$, differences in glycerol levels for Vuse nonmenthol (29 mg nicotine/cartridge) and Vuse menthol were significant $(\mathrm{p}<0.05)$ (Table 3$)$. Mean $\mathrm{TWA}_{\mathrm{BC}}$ for propylene glycol was nearly five times higher for Vuse menthol than for Newport Box CC, a comparison that was also statistically significant $(\mathrm{p}<0.05)$.

Emission factors were calculated for all SHV and SHS constituents. Emission factors were only reported for constituents for which the uncorrected chamber concentration from the study product was statistically significantly greater than that of its respective blank. Table 4 summarizes the emission factor results for CC and ENDS (mg/cigarette or $\mathrm{mg} / 10 \mathrm{~min}$ vaping).

A total of 20 cartridges each of Vuse Menthol, Vuse Original, and Vuse Original Silver were provided to 12 participants in each of Cohorts 3, 4, and 5, respectively. These cartridges were used for product use (vaping) runs in the chamber. The mass of e-liquid (g) used by participants in Cohorts 3, 4, and 5 is summarized in Table 5 . The mass of e-liquid consumed during use of the market sample products was not measured. Table 6 lists the emission factor results for Vuse products (only) in units of $\mu \mathrm{g} / \mathrm{mg}$ e-liquid consumed. Reporting as $\mu \mathrm{g} / \mathrm{mg}$ e-liquid may be useful for modeling of emissions from the Vuse products over a typical day's usage. Among the three Vuse products, mean emission factors ( $\mu \mathrm{g} / \mathrm{mg}$ of e-liquid) were similar with the exception of propylene glycol, which was higher for Vuse menthol than for Vuse non-menthol (29 mg nicotine/cartridge) and Vuse non-menthol (14 mg nicotine/cartridge) $(171,22$, and 22 $\mu \mathrm{g} / \mathrm{mg}$ of e-liquid, respectively) (Table 6). 


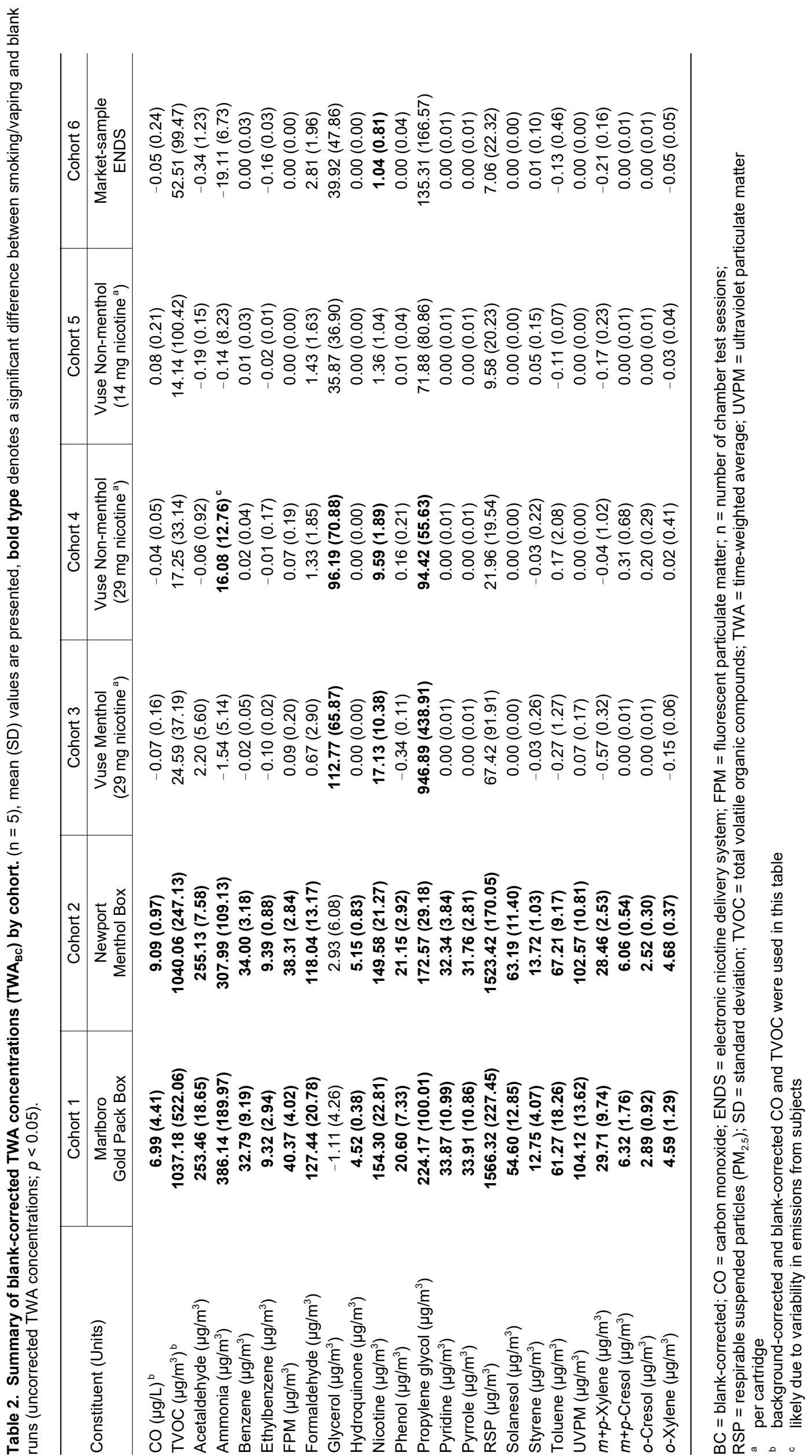


Table 3. Statistical comparison ( $p$-values) of blank-corrected TWA concentration (TWA $\mathrm{BC}_{\mathrm{BC}}$ ) between test and reference products ${ }^{\mathrm{a}}$. $p$-Values are from 2-sample 2-tailed $t$-test; bold type denotes significant values $(p<0.05)$.

\begin{tabular}{|c|c|c|c|c|c|}
\hline Constituent & $\begin{array}{l}\text { Vuse Non-menthol } \\
\left(29 \text { mg nicotine }{ }^{b}\right) \text { vs } \\
\text { Marlboro Gold Pack Box }\end{array}$ & $\begin{array}{l}\text { Vuse Non-menthol } \\
\left(14 \text { mg nicotine }{ }^{b}\right) \text { vs } \\
\text { Marlboro Gold Pack Box }\end{array}$ & $\begin{array}{c}\text { Vuse Menthol } \\
\left(29 \text { mg nicotine }^{b}\right) \text { vs } \\
\text { Newport Box }\end{array}$ & \begin{tabular}{|c|} 
Market-sample \\
ENDS vs \\
Marlboro Gold Pack Box
\end{tabular} & $\begin{array}{l}\text { Market-sample } \\
\text { ENDS vs } \\
\text { Newport Box }\end{array}$ \\
\hline $\mathrm{CO}$ & 0.023 & 0.025 & $<0.001$ & 0.023 & $<0.001$ \\
\hline TVOC & 0.012 & 0.011 & $<0.001$ & 0.012 & $<0.001$ \\
\hline Acetaldehyde & $<0.001$ & $<0.001$ & $<0.001$ & $<0.001$ & $<0.001$ \\
\hline Ammonia & 0.012 & 0.010 & 0.003 & 0.009 & 0.003 \\
\hline Benzene & 0.001 & 0.001 & $<0.001$ & 0.001 & $<0.001$ \\
\hline Ethylbenzene & 0.002 & 0.002 & $<0.001$ & 0.002 & $<0.001$ \\
\hline FPM & $<0.001$ & $<0.001$ & $<0.001$ & $<0.001$ & $<0.001$ \\
\hline Formaldehyde & $<0.001$ & $<0.001$ & $<0.001$ & $<0.001$ & $<0.001$ \\
\hline Glycerol & 0.037 & 0.088 & 0.020 & 0.128 & 0.159 \\
\hline Hydroquinone & $<0.001$ & $<0.001$ & $<0.001$ & $<0.001$ & $<0.001$ \\
\hline Nicotine & $<0.001$ & $<0.001$ & $<0.001$ & $<0.001$ & $<0.001$ \\
\hline Phenol & 0.003 & 0.003 & $<0.001$ & 0.003 & $<0.001$ \\
\hline Propylene glycol & 0.035 & 0.029 & 0.017 & 0.336 & 0.647 \\
\hline Pyridine & 0.002 & 0.002 & $<0.001$ & 0.002 & $<0.001$ \\
\hline Pyrrole & 0.002 & 0.002 & $<0.001$ & 0.002 & $<0.001$ \\
\hline RSP & $<0.001$ & $<0.001$ & $<0.001$ & $<0.001$ & $<0.001$ \\
\hline Solanesol & $<0.001$ & $<0.001$ & $<0.001$ & $<0.001$ & $<0.001$ \\
\hline Styrene & 0.002 & 0.002 & $<0.001$ & 0.002 & $<0.001$ \\
\hline Toluene & 0.002 & 0.002 & $<0.001$ & 0.002 & $<0.001$ \\
\hline UVPM & $<0.001$ & $<0.001$ & $<0.001$ & $<0.001$ & $<0.001$ \\
\hline$m+p$-Xylene & 0.002 & 0.002 & $<0.001$ & 0.002 & $<0.001$ \\
\hline$m+p$-Cresol & $<0.001$ & 0.001 & $<0.001$ & 0.001 & $<0.001$ \\
\hline o-Cresol & 0.002 & 0.002 & $<0.001$ & 0.002 & $<0.001$ \\
\hline o-Xylene & $<0.001$ & 0.001 & $<0.001$ & 0.001 & $<0.001$ \\
\hline
\end{tabular}

$\mathrm{BC}=$ blank-corrected $; \mathrm{CO}=$ carbon monoxide ENDS = electronic nicotine delivery system; FPM = fluorescent particulate matter; $\mathrm{RSP}=$ respirable suspended particles $\left(\mathrm{PM}_{2.5}\right) ; \mathrm{TVOC}=$ total volatile organic compounds; TWA = time-weighted average;

UVPM = ultraviolet particulate matter

a background-corrected and blank-corrected values were used in the analysis

b per cartridge 
Table 4. Summary of mean (SD) emission factors for analytes ( $\mathrm{mg} /$ cigarette or $\mathrm{mg} / 10 \mathrm{~min}$ vaping) by cohort.

\begin{tabular}{|c|c|c|c|c|c|c|}
\hline & Cohort 1 & Cohort 2 & Cohort 3 & Cohort 4 & Cohort 5 & Cohort 6 \\
\hline Constituent & $\begin{array}{c}\text { Marlboro } \\
\text { Gold Pack Box } \\
(n=5)\end{array}$ & $\begin{array}{c}\text { Newport } \\
\text { Menthol Box } \\
(n=5)\end{array}$ & $\begin{array}{c}\text { Vuse Menthol } \\
\left(29 \mathrm{mg} \mathrm{nicotine}^{*}\right) \\
(\mathrm{n}=5)\end{array}$ & 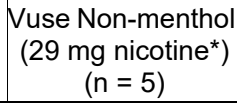 & $\begin{array}{c}\text { Vuse Non-menthol } \\
\left(14 \text { mg nicotine }^{*}\right) \\
(\mathrm{n}=5)\end{array}$ & $\begin{array}{c}\text { Market-sample } \\
\text { ENDS } \\
(\mathrm{n}=5)\end{array}$ \\
\hline Acetaldehyde & $1.921(0.128)$ & $1.937(0.033)$ & $\mathrm{N} / \mathrm{A}$ & N/A & $\mathrm{N} / \mathrm{A}$ & $N / A$ \\
\hline Ammonia & $2.925(1.444)$ & $2.336(0.815)$ & $\mathrm{N} / \mathrm{A}$ & $0.125(0.100)$ & N/A & N/A \\
\hline Benzene & $0.249(0.070)$ & $0.258(0.022)$ & $\mathrm{N} / \mathrm{A}$ & N/A & $\mathrm{N} / \mathrm{A}$ & $N / A$ \\
\hline $\mathrm{CO}$ & 56.540 (31.549) & $72.433(7.131)$ & $\mathrm{N} / \mathrm{A}$ & N/A & $N / A$ & $N / A$ \\
\hline Ethylbenzene & $0.071(0.022)$ & $0.071(0.006)$ & $\mathrm{N} / \mathrm{A}$ & N/A & $\mathrm{N} / \mathrm{A}$ & $N / A$ \\
\hline FPM & $0.306(0.028)$ & $0.291(0.017)$ & $\mathrm{N} / \mathrm{A}$ & N/A & N/A & $\mathrm{N} / \mathrm{A}$ \\
\hline Formaldehyde & $0.966(0.156)$ & $0.896(0.095)$ & $\mathrm{N} / \mathrm{A}$ & N/A & N/A & N/A \\
\hline Glycerol & $\mathrm{N} / \mathrm{A}$ & $\mathrm{N} / \mathrm{A}$ & $0.872(0.501)$ & $0.752(0.558)$ & N/A & $\mathrm{N} / \mathrm{A}$ \\
\hline Hydroquinone & $0.034(0.003)$ & $0.039(0.006)$ & $N / A$ & N/A & $\mathrm{N} / \mathrm{A}$ & N/A \\
\hline Nicotine & $1.170(0.176)$ & $1.136(0.166)$ & $0.133(0.080)$ & $0.075(0.015)$ & $\mathrm{N} / \mathrm{A}$ & $0.008(0.006)$ \\
\hline Phenol & $0.156(0.056)$ & $0.160(0.019)$ & $\mathrm{N} / \mathrm{A}$ & N/A & $\mathrm{N} / \mathrm{A}$ & N/A \\
\hline Propylene glycol & $1.701(0.765)$ & $1.308(0.206)$ & $7.326(3.343)$ & $0.736(0.432)$ & $\mathrm{N} / \mathrm{A}$ & $N / A$ \\
\hline Pyridine & $0.257(0.084)$ & $0.245(0.025)$ & $\mathrm{N} / \mathrm{A}$ & N/A & N/A & N/A \\
\hline Pyrrole & $0.257(0.083)$ & $0.241(0.018)$ & $\mathrm{N} / \mathrm{A}$ & N/A & N/A & $N / A$ \\
\hline RSP & $11.863(1.612)$ & $11.551(1.088)$ & $\mathrm{N} / \mathrm{A}$ & N/A & $\mathrm{N} / \mathrm{A}$ & $N / A$ \\
\hline Solanesol & $0.414(0.095)$ & $0.479(0.082)$ & $\mathrm{N} / \mathrm{A}$ & N/A & $N / A$ & $N / A$ \\
\hline Styrene & $0.097(0.031)$ & $0.104(0.006)$ & $\mathrm{N} / \mathrm{A}$ & N/A & N/A & $\mathrm{N} / \mathrm{A}$ \\
\hline TVOC & $7.850(3.853)$ & $7.836(1.800)$ & $\mathrm{N} / \mathrm{A}$ & $N / A$ & $\mathrm{~N} / \mathrm{A}$ & $N / A$ \\
\hline Toluene & $0.465(0.139)$ & $0.510(0.069)$ & $\mathrm{N} / \mathrm{A}$ & $N / A$ & $\mathrm{~N} / \mathrm{A}$ & $N / A$ \\
\hline UVPM & $0.789(0.097)$ & $0.778(0.069)$ & $\mathrm{N} / \mathrm{A}$ & N/A & $N / A$ & $N / A$ \\
\hline$m+p$-Xylene & $0.225(0.074)$ & $0.216(0.016)$ & $\mathrm{N} / \mathrm{A}$ & $N / A$ & N/A & N/A \\
\hline$m+p$-Cresol & $0.048(0.013)$ & $0.046(0.003)$ & $\mathrm{N} / \mathrm{A}$ & $N / A$ & N/A & N/A \\
\hline o-Cresol & $0.022(0.007)$ & $0.019(0.002)$ & $\mathrm{N} / \mathrm{A}$ & N/A & N/A & N/A \\
\hline o-Xylene & $0.035(0.010)$ & $0.036(0.002)$ & $\mathrm{N} / \mathrm{A}$ & N/A & N/A & $N / A$ \\
\hline
\end{tabular}

$\mathrm{CO}=$ carbon monoxide; ENDS = electronic nicotine delivery system; FPM = fluorescent particulate matter; $\mathrm{n}=$ number of chamber test sessions; N/A = uncorrected mean TWA concentration not significantly different from blank; RSP = respirable suspended particles $\left(\mathrm{PM}_{2.5}\right)$; $\mathrm{SD}=$ standard deviation; TVOC = total volatile organic compounds; UVPM = ultraviolet particulate matter.

* per cartridge; mean (SD) are presented

Table 5. Summary of mass of e-liquid (g) used by cohort.

\begin{tabular}{l|c|c|c|c|c|c}
\hline Cohort No. & $\mathrm{n}$ & Mean & Median & SD & Minimum & Maximum \\
\hline 3 Vuse Menthol & 20 & 0.043 & 0.0405 & 0.027 & 0.0012 & 0.0941 \\
4 Vuse Original & 20 & 0.032 & 0.0336 & 0.018 & 0.0037 & 0.0700 \\
5 Vuse Original Silver & 20 & 0.023 & 0.0234 & 0.019 & 0.0009 & 0.0629 \\
\hline
\end{tabular}

$\mathrm{n}=$ number of cartridges from all smoking runs;

$\mathrm{SD}=$ standard deviation 
Table 6. Summary of mean (SD) emission factors for analytes ( $\mu \mathrm{g} / \mathrm{mg}$ of e-liquid) for Vuse*

\begin{tabular}{|c|c|c|c|}
\hline \multirow[b]{2}{*}{ Constituent } & Cohort 3 & Cohort 4 & Cohort 5 \\
\hline & $\begin{array}{c}\text { Vuse Menthol } \\
\left(29 \text { mg nicotine }{ }^{\star \star}\right) \\
(n=5)\end{array}$ & $\begin{array}{c}\text { Vuse Non-menthol } \\
\left(29 \text { mg nicotine }{ }^{\star *}\right) \\
(n=5)\end{array}$ & $\begin{array}{l}\text { Vuse Non-menthol } \\
\left(\begin{array}{c}14 \text { mg nicotine } \\
\text { ** }\end{array}\right) \\
(n=5)\end{array}$ \\
\hline Acetaldehyde & N/A & N/A & $\mathrm{N} / \mathrm{A}$ \\
\hline Ammonia & $\mathrm{N} / \mathrm{A}$ & $3.912(2.786)$ & $\mathrm{N} / \mathrm{A}$ \\
\hline Benzene & $\mathrm{N} / \mathrm{A}$ & N/A & $\mathrm{N} / \mathrm{A}$ \\
\hline $\mathrm{CO}$ & $\mathrm{N} / \mathrm{A}$ & N/A & $\mathrm{N} / \mathrm{A}$ \\
\hline Ethylbenzene & $\mathrm{N} / \mathrm{A}$ & N/A & $\mathrm{N} / \mathrm{A}$ \\
\hline FPM & $\mathrm{N} / \mathrm{A}$ & N/A & $\mathrm{N} / \mathrm{A}$ \\
\hline Formaldehyde & $\mathrm{N} / \mathrm{A}$ & $\mathrm{N} / \mathrm{A}$ & $\mathrm{N} / \mathrm{A}$ \\
\hline Glycerol & $19.528(4.981)$ & 22.395 (14.435) & $\mathrm{N} / \mathrm{A}$ \\
\hline Hydroquinone & N/A & N/A & N/A \\
\hline Nicotine & $2.965(0.594)$ & $2.413(0.443)$ & N/A \\
\hline Phenol & N/A & $\mathrm{N} / \mathrm{A}$ & $\mathrm{N} / \mathrm{A}$ \\
\hline Propylene glycol & 170.986 (10.553) & 22.447 (12.862) & $\mathrm{N} / \mathrm{A}$ \\
\hline Pyridine & $\mathrm{N} / \mathrm{A}$ & $\mathrm{N} / \mathrm{A}$ & $\mathrm{N} / \mathrm{A}$ \\
\hline Pyrrole & $\mathrm{N} / \mathrm{A}$ & $\mathrm{N} / \mathrm{A}$ & $\mathrm{N} / \mathrm{A}$ \\
\hline RSP & $\mathrm{N} / \mathrm{A}$ & $\mathrm{N} / \mathrm{A}$ & $\mathrm{N} / \mathrm{A}$ \\
\hline Solanesol & $\mathrm{N} / \mathrm{A}$ & $\mathrm{N} / \mathrm{A}$ & N/A \\
\hline Styrene & $\mathrm{N} / \mathrm{A}$ & $N / A$ & N/A \\
\hline TVOC & $\mathrm{N} / \mathrm{A}$ & $\mathrm{N} / \mathrm{A}$ & $\mathrm{N} / \mathrm{A}$ \\
\hline Toluene & $\mathrm{N} / \mathrm{A}$ & $\mathrm{N} / \mathrm{A}$ & $\mathrm{N} / \mathrm{A}$ \\
\hline UVPM & N/A & $\mathrm{N} / \mathrm{A}$ & N/A \\
\hline$m+p$-Xylene & N/A & $\mathrm{N} / \mathrm{A}$ & $\mathrm{N} / \mathrm{A}$ \\
\hline$m+p$-Cresol & N/A & N/A & N/A \\
\hline o-Cresol & N/A & N/A & N/A \\
\hline o-Xylene & N/A & $\mathrm{N} / \mathrm{A}$ & N/A \\
\hline
\end{tabular}

$\mathrm{CO}=$ carbon monoxide; $\mathrm{FPM}$ = fluorescent particulate matter; $\mathrm{n}=$ number of chamber test sessions; N/A = not significantly different from background; RSP = respirable suspended particles; $\mathrm{SD}=$ standard deviation; TVOC = total volatile organic compounds; UVPM = ultraviolet particulate matter; * Mass of e-liquid consumed during use was not determined for market sample products; ** per cartridge; mean (SD) are presented

\section{DISCUSSION}

There is limited data available on the composition of emissions of SHV from ENDS. Previous studies have focused on emissions generated in poorly controlled conditions and naturalistic environments, including homes and offices $(16,20,25,26)$. Other studies used methods that may not have been appropriately validated or used industrial hygiene methods for comparison to acceptable occupational health exposure levels $(18,25)$. Some of the compounds measured in this study have been detected in exhaled breath of smokers and non-smokers $(44,45)$, and some previous studies were limited because their methodology did not include determination of background concentrations from study participants $(18,25,26)$.

In this study, the emissions of SHV constituents from cig-alike ENDS were evaluated and emission factors determined. This is the first well-controlled study conducted at exaggerated smoke concentrations designed to maximize detection of SHV and SHS constituents from each of the test products. Respirable suspended particle levels after CC smoking were similar between this study and a previous study of cigarettes. This suggests that chamber smoke levels in this study are most likely 10-40 times greater than smoke levels in indoor environments when indoor smoking was more widespread (28). The use of an environmental testing chamber in this study allowed reliable generation of SHV and SHS while controlling many confounders (28). This study also used carefully controlled blank runs where the same methodology was followed except subjects did not use study products while in the chamber. The blank runs permitted determination of constituent concentrations that may arise from people separate from those that arise from product usage. All analytical methods used were validated at the concentrations expected in background air. Results of this investigation show that SHV from cig-a-like ENDS is both qualitatively and quantitatively different from SHS from CC. Concentrations of most SHV constituents from ENDS were not statistically significantly different $(p<0.05)$ from blank. For many of these constituents, secondhand emissions from ENDS were comparable to or lower than emissions from blank runs. This resulted in blank-corrected TWA concentrations that were nil or negative. Additionally, SHV constituent concentrations from ENDS were reduced by nearly $100 \%$ relative to SHS from cigarettes. Exceptions included components of the e-liquid used for aerosol formation in the ENDS (i.e., propylene glycol and glycerol).

In the U.S., the Occupational Safety and Health Administration (OSHA) regulates glycerol as a dust with permissible 8 -h TWA concentrations of $15 \mathrm{mg} / \mathrm{m}^{3}$ total dust and $5 \mathrm{mg} / \mathrm{m}^{3}$ respirable fraction. The UK regulates exposure to glycerol as a mist and has set a TWA of $10 \mathrm{mg} / \mathrm{m}^{3}$ (46), and the German Research Foundation (DFG) has set a maximum workplace concentration (MAK value) of $200 \mathrm{mg} / \mathrm{m}^{3}$ for glycerol (47). The highest glycerol concentrations measured in the chamber after ENDS use were approximately fifty-fold lower than the lowest of these TWA limits. Exposure limits for propylene glycol range from $60 \mu \mathrm{g} / \mathrm{m}^{3}$ to $53.8 \mathrm{mg} / \mathrm{m}^{3}$ (Additional Table A3) (48-51). The majority of the reference values were derived from data in a subchronic rat inhalation study where nasal hemorrhaging was observed, presumably due to a drying effect of propylene glycol on peripheral tissues (52) or formation of 2hydroxypropanal (53). Based upon the data reported in this study, it is expected that propylene glycol concentrations in spaces where vaping is permitted would be expected to fall in the range of $2-95 \mu \mathrm{g} / \mathrm{m}^{3}$. While the most conservative reference limit is in this range, the concentration is well below other exposure limits derived from the same data. Furthermore, it should be noted that no reports of nasal hemorrhaging in vapers (the most exposed population) or in any studies of SHV from ENDS were found in the literature.

Nicotine was present in the SHV from ENDS, though concentrations were $88-99 \%$ lower than those from cigarettes. This is due to the lack of sidestream smoke from ENDS. The ENDS with higher concentrations of nicotine in the e-liquid tended to have higher levels of nicotine in their SHV. Nicotine levels measured in the chamber for both cigarettes and ENDS were well below the American Conference of Governmental Industrial Hygienists $\left(\mathrm{ACGIH}^{\circledR}\right)$ occupational exposure level $\left(500 \mu \mathrm{g} / \mathrm{m}^{3}\right)(50)$. A number of investigators have reported detecting formaldehyde and acetaldehyde in the mainstream aerosol of 
ENDS (6, 54-56) with others detecting formaldehyde in SHV studies $(18,29)$. These authors concluded that the concentrations found are likely due to background rather than emissions from the ENDS. It is notable here that no statistically significant difference in formaldehyde or acetaldehyde concentration was observed between any of the ENDS and their respective blanks. Considering WHO and EU guidelines, the nominal differences in formaldehyde or acetaldehyde over blank would not contribute significantly to indoor air quality $(57,58)$.

Ammonia from one of the four ENDS products (Vuse nonmenthol (29 mg nicotine/cartridge)) was measurable and discernible from the blank concentration. In comparison, the mean $\mathrm{TWA}_{\mathrm{BC}}$ concentration of ammonia from this product $\left(16.08 \mu \mathrm{g} / \mathrm{m}^{3}\right)$ was approximately six times below an indoor air quality guideline value $\left(10 \mu \mathrm{g} / \mathrm{m}^{3}\right)$ and at least four times lower than exposure concentrations that could be easily obtained from using ammonia-containing household products (58). There is no detectable ammonia in the vapor of any of the Vuse products. Human exhaled breath contains detectable levels of ammonia $(59,60)$. Consequently, it is likely that the measured chamber concentrations of ammonia after use of this product are due to variability in emissions from subjects in the VUSE nonmenthol ( $29 \mathrm{mg} /$ cartridge) rather than product (note higher standard deviation in Vuse non-menthol (29 mg nicotine/cartridge) compared to other ENDS).

Among the Vuse products, mean blank-corrected TWA concentration for propylene glycol was higher for Vuse menthol than for Vuse non-menthol products. Menthol is more soluble in propylene glycol than glycerol. The concentration of propylene glycol in the e-liquid of the menthol product is likely different than that of the non-menthol product. Differences in propylene glycol concentration in the e-liquids would result in differences in the aerosols generated by the products. The Vuse menthol group vaped more e-liquid during the test sessions than the Vuse nonmenthol groups (Table 5); this also may have contributed to the observed differences in propylene glycol emissions. Emission factors (emission rates) are an important input for modeling the effect of smoking/ENDS use on indoor air quality $(53,61-62)$. Even under the exaggerated conditions of the methodology used for this study, some SHV constituent emissions from ENDS were not discernable from concentrations measured during blank chamber runs. Constituent emissions not reliably distinguished from blank do not likely make a significant contribution to indoor air quality at normal use levels, and emission factors calculated from those chamber concentrations would not be meaningful. Emission factors for the CC generally agree with those determined in a previous study (31). An exception was TVOC. This discrepancy could be a result of differences between the study product and methodology. In particular, TVOC was measured in the two studies by different analytical techniques (photo $v s$. flame ionization detection) with different detection methods and calibration types. Particulate matter was measured as RSP $\left(\mathrm{PM}_{2.5}\right)$, UVPM, and FPM. The aerosol generated by cigarettes and vapor products is a condensation aerosol. The particles are ultrafine and fall into the $\mathrm{PM}_{2.5}$ (particulate matter $<2.5 \mu \mathrm{m}$ ) range. RSP was not detected above background for the ENDS in the chamber tests. This is due to the volatility of the major components of the ENDS aerosol (glycerol, propylene glycol, nicotine and water) which evaporate quickly upon dilution $(63,64)$ and is demonstrated in this study by collection of propylene glycol and glycerol in the vapor phase adsorbent methods, rather than as RSP on the pads. UVPM and FPM are a further way to differentiate combustion-related aerosols from other fine particulates (65-67). For combustible cigarettes, UVPM and FPM were significantly elevated above background indicating the presence of combustion particles in the smoke. For the ENDS, RSP was non-significantly elevated above background and UVPM and FPM were close to zero which is indicative of the non-combustion related source of the particles.

This study was limited to the evaluation of cig-a-like ENDS. Other types of ENDS that generate higher levels of mainstream aerosol were not tested. Nevertheless, the composition of vapor from other types of ENDS is expected to be qualitatively similar to that of cig-a-likes in that they are not expected to contain most typical combustion products from tobacco. Moreover, the composition of aerosol from nearly all ENDS is likely to be dramatically different from that of combustible tobacco products.

\section{CONCLUSIONS}

Levels of toxicants have been demonstrated to be lower in the inhaled vapor from ENDS relative to combustible cigarettes (10-12). Similarly, secondhand vapor from ENDS differs qualitatively and quantitatively from the emissions of tobacco-burning cigarettes. Even at the highly exaggerated concentrations evaluated in this study, most of the components measured in the SHV from ENDS were not discernable from the background levels. In the few cases where increases were noted, the concentrations were low, represent an overestimation of normal conditions, and are likely lower in more typical smoking environments. Such concentrations fall below levels that have been associated with adverse health impacts. Additionally, the majority of compounds were dramatically reduced relative to the levels found in SHS from the CC comparators. Although the longterm health effects of ENDS use are not yet known, levels of SHS constituents in SHV were low and would not be expected to contribute significantly to contamination of indoor air relative to $\mathrm{CC}$. 


\begin{tabular}{ll}
\hline LIST OF & ABBREVIATIONS \\
\hline CC & combustible cigarettes \\
ENDS & electronic nicotine delivery systems \\
ETS & environmental tobacco smoke \\
FPM & fluorescent particulate matter \\
LLOQ & lower limit of quantification \\
PAH & polycyclic aromatic hydrocarbon \\
PID & photoionization detection \\
PM & particulate matter \\
RH & relative humidity \\
RSP & respirable suspended particles \\
SHS & secondhand smoke \\
SHV & secondhand vapor \\
TPM & total particulate matter \\
TVOC & total volatile organic compounds \\
TWA & time-weighted average \\
UVPM & ultraviolet particulate matter \\
VOCs & volatile organic compounds \\
\hline
\end{tabular}

\section{DECLARATIONS}

Availability of data and materials: Not applicable.

Competing interests: J.W. Caraway was a full-time employee of RAI Services Company at the time of study conduct and is currently a full-time employee of R.J. Reynolds Tobacco Company. T. Jin, E. Schmidt, and P. Nelson are full-time employees of RAI Services Company. RAI Services Company and R.J. Reynolds Tobacco Company are wholly owned subsidiaries of Reynolds American Inc., which is a wholly owned subsidiary of British American Tobacco plc.

Funding: This study was funded by RJR Vapor Company through R.J. Reynolds Tobacco Company.

Acknowledgements: The authors would like to acknowledge the following for their contributions to this work: Mark Rigler and Kevin Simpson from Materials Analytical Services, LLC (MAS) and the staff of MAS, Clinical Research Atlanta, and Covance, Inc. who were involved in the execution of the clinical study. Megan J. Whelen assisted with reviewing and editing the manuscript.

Additional file 1: Summary of uncorrected TWA concentrations and statistical comparisons of uncorrected TWA concentrations from product smoking/vaping and blank runs, and exposure limits for propylene glycol.

\section{REFERENCES}

1. Rodgman, A: Environmental Tobacco Smoke; Regul. Toxicol. Pharmacol. 16 (1992) 223-244. DOI: 10.1016/0273-2300(92)90003-r

2. Soule, E.K., S.F. Maloney, T.R. Spindle, A.K. Rudy, M.M. Hiler, and C.O. Cobb: Electronic Cigarette Use and Indoor Air Quality in a Natural Setting; Tob. Control 26 (2017) 109-112.

DOI: 10.1136/tobaccocontrol-2015-052772
3. World Health Organization (WHO) Study Group on Tobacco Regulation: Tobreg Scientific Recommendation: Devices Designed for the Purpose of Nicotine Delivery to the Respiratory System in Which Tobacco is not Necessary for Their Operation; in: Report on the Scientific Basis of Product Regulation: Third Report of a WHO Study Group. WHO Technical Report Series 955; WHO, Geneva, Switzerland, 2009, pp. 3-13.

4. Farsalinos, K.E. and R. Polosa: Safety Evaluation and Risk Assessment of Electronic Cigarettes as Tobacco Cigarette Substitutes: A Systematic Review; Ther. Adv. Drug Saf. 5 (2014) 67-86.

DOI: $10.1177 / 2042098614524430$

5. Abrams, D.B. and R. Niaura: The Importance of Science-Informed Policy and what the Data Really Tell us About E-cigarettes; Isr. J. Health Policy Res. 4 (2015) 22. DOI: 10.1186/s13584-015-0021-z

6. Goniewicz, M.L., J. Knysak, M. Gawron, L. Kosmider, A. Sobczak, J. Kurek, A. Prokopowicz, M. JablonskaCzapla, C. Rosik-Dulewska, C. Havel, P. Jacob III, and N. Benowitz: Levels of Selected Carcinogens and Toxicants in Vapour from Electronic Cigarettes; Tob. Control 23 (2014) 133-139.

DOI: 10.1136/tobaccocontrol-2012-050859

7. Hajek, P., J.F. Etter, N. Benowitz, T. Eissenberg, and H. McRobbie: Electronic Cigarettes: Review of Use, Content, Safety, Effects on Smokers and Potential for Harm and Benefit; Addiction 109 (2014) 1801-1810. DOI: 10.1111/add.12659

8. Hecht, S.S., S.G. Carmella, D. Kotandeniya, M.E. Pillsbury, M. Chen, B.W. Ransom, R.I. Vogel, E. Thompson, S.E. Murphy, and D.K. Hatsukami: Evaluation of Toxicant and Carcinogen Metabolites in the Urine of E-cigarette Users Versus Cigarette Smokers; Nicotine Tob. Res. 17 (2015) 704-709.

DOI: $10.1093 / \mathrm{ntr} / \mathrm{ntu} 218$

9. U.S. Department of Health and Human Services (HHS): The Health Consequences of Smoking - 50 Years of Progress: A Report of the Surgeon General; Centers for Disease Control and Prevention, Atlanta, GA, USA, 2014. Available at: https://www.ncbi.nlm. nih.gov/books/NBK179276/ (accessed February 2021)

10. Marcham, C.L. and J.P. Springston: Electronic Cigarettes in the Indoor Environment; Rev. Environ. Health 34 (2019) 105-124. DOI: 10.1515/reveh-2019-0012

11. Belushkin, M., D.T. Djoko, M. Esposito, A. Korneliou, C. Jeannet, M. Lazzerini, and G. Jaccard: Selected Harmful and Potentially Harmful Consitutents Levels in Commercial E-cigarettes; Chem. Res. Toxicol. 33 (2019) 657-668.

DOI: $10.1021 /$ acs.chemrestox.9b00470

12. van Drooge, B., E. Marco, N. Perez, and J.O. Grimalt: Influence of Electronic Cigarette Vaping on the Composition of Indoor Organic Pollutants, Particles, and Exhaled Breath of Bystanders; Environ. Sci. Pollut. Res. Int. 26 (2018) 4654-4666. DOI: $10.1007 / \mathrm{s} 11356-018-3975-\mathrm{x}$

13. Burstyn, I.: Peering Through the Mist: Systematic Review of what the Chemistry of Contaminants in Electronic Cigarettes Tells us About Health Risks; BMC Public Health 14 (2014) 18.

DOI: $10.1186 / 1471-2458-14-18$ 
14. Chang, H.: Research Gaps Related to the Environmental Impacts of Electronic Cigarettes; Tob. Control 23, Suppl. 2 (2014) ii54-ii58.

DOI: $10.1136 /$ tobaccocontrol-2013-051480

15. Melstrom, P., B. Koszowski, M.H. Thanner, E. Hoh, B. King, R. Bunnell, and T. McAfee: Measuring $\mathrm{PM}_{2.5}$, Ultrafine Particles, Nicotine Air and Wipe Samples Following the Use of Electronic Cigarettes; Nicotine Tob. Res. 19 (2017) 1055-1061.

DOI: $10.1093 / \mathrm{ntr} / \mathrm{ntx} 058$

16. O'Connell, G., S. Colard, X. Cahours, and J.D. Pritchard: An Assessment of Indoor Air Quality Before, During and After Unrestricted Use of E-cigarettes in a Small Room; Int. J. Environ. Res. Public. Health. 12 (2015) 4889-4907.

DOI: $10.3390 /$ ijerph120504889

17. Geiss, O., I. Bianchi, F. Barahona, and J. BarreroMoreno: Characterisation of Mainstream and Passive Vapours Emitted by Selected Electronic Cigarettes; Int. J. Hyg. Environ. Health 218 (2015) 169-180.

DOI: 10.1016/j.ijheh.2014.10.001

18. Maloney, J.C., M.K. Thompson, M.J. Oldham, C.L. Stiff, P.D. Lilly, G.J. Patskan, K.H. Shafer, and M.A. Sarkar: Insights from Two Industrial Hygiene Pilot E-cigarette Passive Vaping Studies; J. Occup. Environ. Hyg. 13 (2016) 275-283.

DOI: $10.1080 / 15459624.2015 .1116693$

19. Zainol Abidin, N., E. Zainal Abidin, A. Zulkifli, K. Karuppiah, S.N. Syed Ismail, and A.S. Amer Nordin: Electronic Cigarettes and Indoor Air Quality: A Review of Studies Using Human Volunteers; Rev. Environ. Health 32 (2017) 235-244.

DOI: $10.1515 /$ reveh-2016-0059

20. Czogala, J., M.L. Goniewicz, B. Fidelus, W. ZielinskaDanch, M.J. Travers, and A. Sobczak: Secondhand Exposure to Vapors from Electronic Cigarettes; Nicotine Tob. Res. 16 (2014) 655-662.

DOI: $10.1093 /$ ntr/ntt203

21. Saffari, A., N. Daher, A. Ruprecht, C. De Marco, P. Pozzi, R. Boffi, S.H. Hamad, M.M. Shafer, J.J. Schauer, D. Westerdahl, and C. Sioutas: Particulate Metals and Organic Compounds from Electronic and Tobacco-Containing Cigarettes: Comparison of Emission Rates and Secondhand Exposure; Environ. Sci. Process. Impacts 16 (2014) 2259-2267.

DOI: $10.1039 / \mathrm{c} 4 \mathrm{em} 00415 \mathrm{a}$

22. Rupprecht, A.A., C. De Marco, A. Saffari, P. Pozzi, R. Mazza, C. Veronese, G. Angellotti, E. Munarini, A.C. Ogliari, D. Westerdahl, S. Hasheminassab, M.M. Shafer, J.J. Schauer, J. Repace, C. Sioutas, and R. Boffi: Environmental Pollution and Emission Factors of Electronic Cigarettes, Heat-Not-Burn Tobacco Products, and Conventional Cigarettes; Aerosol Sci. Technol. 51 (2017) 674-684.

DOI: 10.1080/02786826.2017.1300231

23. Protano, C., M. Manigrasso, V. Cammalleri, G.B. Zoccai, G. Frati, P. Avino, and M. Vitali: Impact of Electronic Alternatives to Tobacco Cigarettes on Indoor Air Particular Matter Levels; Int. J. Environ. Res. Public Health 17 (2020) E2947.

DOI: 10:3390/ijerph17082947
24. Sadvie, J., N. Canha, N. Buitrago, and S.M. Almeida: Passive Exporure to Pollutants from a New Generation of Cigarettes in Real Life Scenarios; Int. J. Environ. Res. Public Health 17 (2020) 3455.

DOI: $10.3390 /$ ijerph17103455

25. Ballbè, M., J.M. Martinez-Sanchez, X. Sureda, M. Fu, R. Pérez-Ortuño, J.A. Pascual, E. Saltó, and E. Fernandez: Cigarettes vs. E-cigarettes: Passive Exposure at Home Measured by Means of Airborne Marker and Biomarkers; Environ. Res. 135 (2014) 76-80. DOI: 10.1016/j.envres.2014.09.005

26. Schober, W., K. Szendrei, W. Matzen, H. OsianderFuchs, D. Heitmann, T. Schettgen, R.A. Jörres, and A. Fromme: Use of Electronic Cigarettes (E-cigarettes) Impairs Indoor Air Quality and Increases FeNO Levels of E-cigarette Consumers; Int. J. Hyg. Environ. Health. 217 (2014) 628-637. DOI: 10.1016/j.ijheh.2013.11.003

27. Johnson, J.M., L.P. Naeher, X. Yu, S.L. Rathbun, J.L. Muilenburg, and J.S. Wang: Air Monitoring at Large Public Electronic Cigarette Events; Int. J. Hyg. Environ. Health 221 (2018) 541-547.

DOI: $10.1016 /$ j.ijheh.2018.02.003

28. Nelson, P.R., S.P. Kelly, and F.W. Conrad: Studies of Environmental Tobacco Smoke Generated by Different Cigarettes; J. Air Waste Manag. Assoc. 48 (1998) 336-344. DOI: 10.1080/10473289.1998.10463685

29. Schripp, T., D. Markewitz, E. Uhde, and T. Salthammer: Does E-cigarette Consumption Cause Passive Vaping?; Indoor Air 23 (2013) 25-31. DOI: $10.1111 / \mathrm{j} .1600-0668.2012 .00792 . x$

30. Liu, J., Q. Liang, M.J. Oldham, A.A. Rostami, K.A. Wagner, I.G. Gillman, P. Patel, R. Savioz, and M. Sarkar: Determination of Selected Chemical Levels in Room Air and on Surfaces After the Use of Cartridgeand Tank-Based E-Vapor Products or Conventional Cigarettes; Int. J. Environ. Res. Public Health 14 (2017) E969. DOI: 10.3390/ijerph14090969

31. Martin, P., D.L. Heavner, P.R. Nelson, K.C. Maiolo, C.H. Risner, P.S. Simmons, W.T. Morgan, and M.W Ogden: Environmental Tobacco Smoke (ETS): A Market Cigarette Study; Environ. Int. 23 (1997) 75-90. DOI: 10.1016/S0160-4120(96)00079-7

32. Wells Fargo Securities: Nielsen: Tobacco All Channel Data Thru 8/11 - Cig Vol Decelerates. Available at: https://athra.org.au/wp-content/uploads/2018/09/WellsFargo-Nielsen-Tobacco-All-Channel-Report-PeriodEnding-8.11.18.pdf (accessed February 2021)

33. U.S. Food and Drug Administration (FDA): Harmful and Potentially Harmful Constituents in Tobacco Products and Tobacco Smoke, Established List; FDA, 2012. Available at: https://www.federalregister.gov/documents/2012/04/03/ 2012-7727/harmful-and-potentially-harmful-constituentsin-tobacco-products-and-tobacco-smoke-establishedlist (accessed February 2021)

34. U.S. Department of Health and Human Services (HHS), Food and Drug Administration (FDA), Center for Drug Evaluation and Research (CDER), and Center for Vetinary Medicine (CVM): Bioanalytical Method Validation. Guidance for Industry; 2018. Available at: https://www.fda.gov/files/drugs/published/Bioanalyti cal-Method-Validation-Guidance-for-Industry.pdf (accessed February 2021) 
35. European Medicines Agency (EMA): Guideline on Validation of Bioanalytical Methods; London, UK, 2015. Available at: https://www.ema.europa.eu/en/documents/ scientific-guideline/guideline-bioanalytical-methodvalidation_en.pdf (accessed February 2021)

36. U.S. Enivronmental Protection Agency (EPA): Compendium Method TO-17. Determination of Volatile Organic Compounds in Ambient Air Using Active Sampling onto Sorbent Tubes; EPA, Cincinnati, OH, USA, 1999. Available at: https://www3.epa.gov/ttnamti1/files/ ambient/airtox/to-17r.pdf (accessed February 2021)

37. The National Institute for Occupational Safety and Health (NIOSH): Formaldehyde, Method No. 2016. in: NIOSH Manual of Analytical Methods; $4^{\text {th }}$ Edition, 2003. Available at: http://www.cdc.gov/niosh/docs/ 2003-154/pdfs/2016.pdf (accessed February 2021)

38. The National Institute for Occupational Safety and Health (NIOSH): Ammonia by IC, Method No. 6016; in: NIOSH Manual of Analytical Methods; $4^{\text {th }}$ Edition, 2003. Available at: https://www.cdc.gov/niosh/docs/2014151/pdfs/methods/3800.pdf (accessed February 2021)

39. U.S. Department of Labor, Occupational Safety and Health Administration (OSHA): Hydroquinone. Method PV2094; OSHA, Washington, DC, USA, 1994. Available at: https://www.osha.gov/dts/sltc/methods/ partial/pv2094/pv2094.html (accessed February 2021)

40. Cooperation Centre for Scientific Research Relative to Tobacco CORESTA: Recommended Method No. 50. Environmental Tobacco Smoke - Determination of Nicotine and 3-Ethenylpyridine in the Vapor Phase; Paris, France, 2002. Available at: https://www.coresta.org/ sites/default/files/technical_documents/main/CRM_50.pdf (accessed February 2021)

41. The National Institute for Occupational Safety and Health (NIOSH): Particulates not Otherwise Regulated, Total; in: NIOSH Manual of Analytical Methods, $4^{\text {th }}$ Edition, 2003. Available at: https://www.cdc.gov/niosh/ docs/2014-151/pdfs/methods/0501.pdf (accessed February 2021)

42. Cooperation Centre for Scientific Research Relative to Tobacco CORESTA: Recommended Method No. 52. Environmental Tobacco Smoke - Estimation of its Contribution to Respirable Suspended Particles. Method Based on Solanesol Determination; Paris, France, 2002. Available at: https://www.coresta.org/sites/default/files/ technical_documents/main/CRM_52_0.pdf (accessed February 2021)

43. Cooperation Centre for Scientific Research Relative to Tobacco CORESTA: Recommended Method No. 51. Environmental Tobacco Smoke - Estimation of its Contribution to Respirable Suspended Particles - Determination of Particulate Matter by Ultraviolet Absorbance and by Fluorescence; Paris, France, 2003. Available at: https://www.coresta.org/sites/default/files/technical documents/main/CRM_51_0.pdf (accessed February 2021)

44. Riess, U., U. Tegtbur, C. Fauck, F. Fuhrmann, D. Markewitz, and T. Salthammer: Experimental Setup and Analytical Methods for the Non-Invasive Determination of Volatile Organic Compounds, Formaldehyde and $\mathrm{NO}_{\mathrm{x}}$ in Exhaled Human Breath; Anal. Chim. Acta 669 (2010) 53-62. DOI: 10.1016/j.aca.2010.04.049
45. Wallace, L.A. and E.D. Pellizzari: Recent Advances in Measuring Exhaled Breath and Estimating Exposure and Body Burden for Volatile Organic Compounds (VOCs); Environ Health Perspect. 103, Suppl 3 (1995) 95-98. DOI: 10.1289/ehp.95103s395

46. Health and Safety Executive (HSE): EH40/2005 Workplace Exposure Limits. Containing the List of Workplace Exposure Limits for Use with the Control of Substances Hazardous to Health Regulations 2002 (as amended); January 2020. Available at: https://www.hse. gov.uk/pubns/books/eh40.htm(accessed February 2021).

47. Deutsche Forschungsgemeinschaft (DFG): List of MAK and BAT Values 2020. Maximum Concentrations and Biological Tolerance Values at the Workplace; Permanent Senate Commission for the Investigation of Health Hazards of Chemical Compounds in the Work Area. Report 56. July 1, 2020. Available at https://series.publisso.de/sites/default/files/documents/ series/mak/lmbv/Vol2020/Iss2/Doc002/mbwl_2020_ eng.pdf (accessed March 2021)

48. German Federal Environmental Protection Agency: Indoor Air Guide Value for Propane-1,2-diol (Propylene Glycol). Communication from the Committee on Indoor Air Guide Values; Bundesgesundheitsblatt 60, (2017) 1298-1304. DOI: 10.1007/s00103-017-2631-9

49. National Research Council of the National Academies, Committee on Spacecraft Exposure Guidelines: Spacecraft Maximum Allowable Concentrations for Selected Airborne Contaminants - Volume 5; Available at: https://www.nap.edu/catalog/12529/spacecraft-maximumallowable-concentrations-for-selected-airbornecontaminants-volume-5 (accessed March 2021)

50. American Conference of Governmental Industrial Hygienists (ACGIH): Guide to Occupational Exposure Values; American Conference of Governmental Industrial Hygienists, Cincinnati, Ohio, USA, 2017.

51. Dutch Expert Committee on Occupational Safety: Propylene Glycol (1,2-Propanediol). Health-Based Recommended Occupational Exposure Limit; Available at https://www.healthcouncil.nl/documents/advisoryreports/2007/10/17/propylene-glycol-12-propanediol (accessed March 2021)

52. Suber, R.L., R. Deskin, I. Nikiforov, X. Fouillet, and C.R.E. Coggins: Subchronic Nose-Only Inhalation Study of Propylene Glycol in Sprague-Dawley Rats; Food Chem. Toxicol. 27 (1989) 573-583.

DOI: 10.1016/0278-6915(89)90016-1

53. Klepeis, N.E. and W.W. Nazaroff: Modeling Residential Exposure to Secondhand Smoke; Atmos. Environ. 40 (2006) 4393-4407. DOI: $10.1016 /$ j.atmosenv.2006.03.018

54. Kosmider, L., A. Sobczak, M. Fik, J. Knysak, M. Zaciera, J. Kurek, and M.L. Goniewicz: Carbonyl Compounds in Electronic Cigarette Vapors: Effects of Nicotine Solvent and Battery Output Voltage; Nicotine Tob. Res. 16 (2014) 1319-1326. DOI: 10.1093/ntr/ntu078

55. Ogunwale, M.A., M. Li, M.V. Ramakrishnam Raju, Y. Chen, M.H. Nantz, D.J. Conklin, and X.A. Fu: Aldehyde Detection in Electronic Cigarette Aerosols; ACS Omega 2 (2017) 1207-1214.

DOI: 10.1021/acsomega.6b00489 
56. Wang, P., W. Chen, J. Liao, T. Matsuo, K. Ito, J. Fowles, D. Shusterman, M. Mendell, and K. Kumagai: A Device-Independent Evaluation of Carbonyl Emissions from Heated Electronic Cigarette Solvents; PLOS ONE 12 (2017) e0169811.

DOI: 10.1371/journal.pone.0169811

57. World Health Organization (WHO): WHO Guidelines for Indoor Air Quality: Selected Pollutants; World Health Organization, Copenhagen, Denmark, 2010. Available at: https://apps.who.int/iris/handle/10665/260127 (accessed February 2021)

58. European Union, EU Science Hub: The INDEX Project. Critical Appraisal of the Setting and Implementation of Indoor Exposure Limits in the EU. Final Report; European Commission Joint Research Centre, Institute for Health and Consumer Protection, Physical and Chemical Exposure Unit, Ispra, Italy, 2005.

59. Brannelly, N.T., J.P. Hamilton-Shield, and A.J. Killard: The Measurement of Ammonia in Human Breath and its Potential in Clinical Diagnostics; Crit. Rev. Anal. Chem. 46 (2016) 490-501.

DOI: $10.1080 / 10408347.2016 .1153949$

60. Hibbard, T. and A.J. Killard: Breath Ammonia Levels in a Normal Human Population Study as Determined by Photoacoustic Laser Spectroscopy; J. Breath Res. 5 (2011) 037101. DOI: 10.1088/1752-7155/5/3/037101

61. Rostami, A.A., Y.B. Pithawalla, J. Liu, M.J. Oldham, K.A. Wagner, K. Frost-Pineda, and M.A. Sarkar: A Well-Mixed Computational Model for Estimating Room Air Levels of Selected Constituents from EVapor Product Use; Int. J. Environ. Res. Public Health 13 (2016) E828. DOI: 10.3390/ijerph13080828

62. Widder, S.H. and L. Haselbach: Relationship Among Concentrations of Indoor Air Contaminants, Their Sources, and Different Mitigation Strategies on Indoor Air Quality; Sustainability 9 (2017) 1149-1165. DOI: $10.3390 / \mathrm{su} 9071149$
63. Ingebrethsen, B.J., S.K. Cole, and S.L. Alderman: Electronic Cigarette Aerosol Particle Size Distribution Measurements; Inhal. Toxicol. 24 (2012) 976-984. DOI: $10.3109 / 08958378.2012 .744781$

64. Martuzevicius, D., T. Prasauskas, A. Setyan, G. O'Connell, X. Cahours, R. Julien, and S. Colard: Characterization of the Spatial and Temporal Dispersion Differences Between Exhaled E-cigarette Mist and Cigarette Smoke; Nicotine Tob. Res. 21 (2019) 1371-1377. DOI: $10.1093 /$ ntr/nty 121

65. Conner, J.M., G.B. Oldaker III, and J.J. Murphy: Method for Assessing the Contribution of Environmental Tobacco Smoke to Respirable Suspended Particles in Indoor Environments; Environ. Technol. 11 (1989) 189-196. DOI: 10.1080/09593339009384855

66. Nelson, P.R., D.L. Heavner, B.B. Collie, K.C. Maiolo, and M.W. Ogden: Effect of Ventilation and Sampling Time on Environmental Tobacco Smoke Component Ratios; Environ. Sci. Technol. 26 (1992) 1909-1915. DOI: $10.1021 / \mathrm{es} 00034 \mathrm{a} 005$

67. Ogden, M.W. and J.D. Richardson: Effect of Lighting and Storage Conditions on the Stability of Ultraviolet Particulate Matter, Fluorescent Particulate Matter, and Solanesol; Tob. Sci. 42 (1998) 10-15.

Corresponding author:

John W. Caraway, PhD

R.J. Reynolds Tobacco Company

401 North Main Street

Winston-Salem, NC 27101

USA

E-Mail: carawaj@rjrt.com 


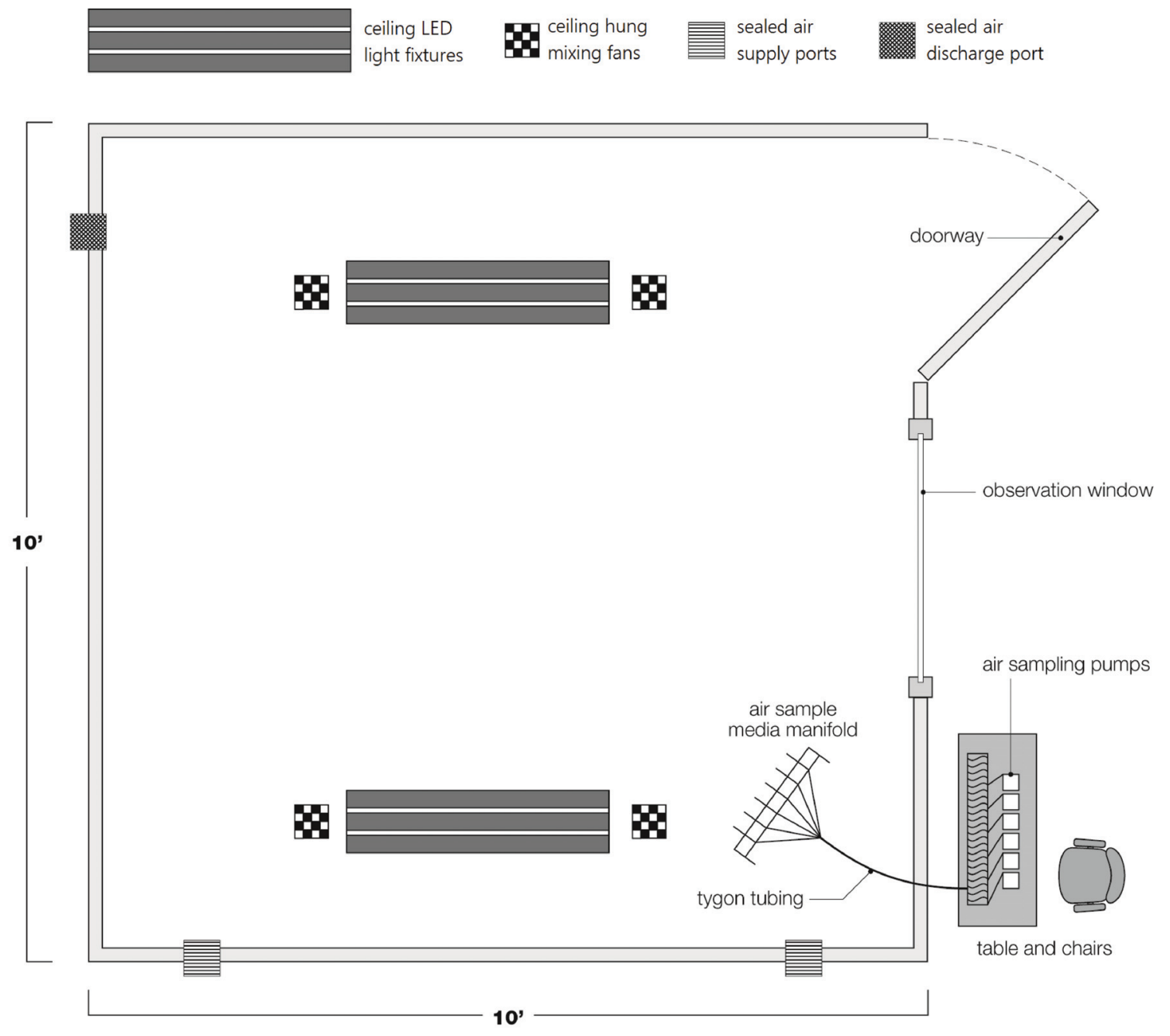

Figure A1. Schematic of environmental test chamber. 
1302-2S1 Newport Menthol

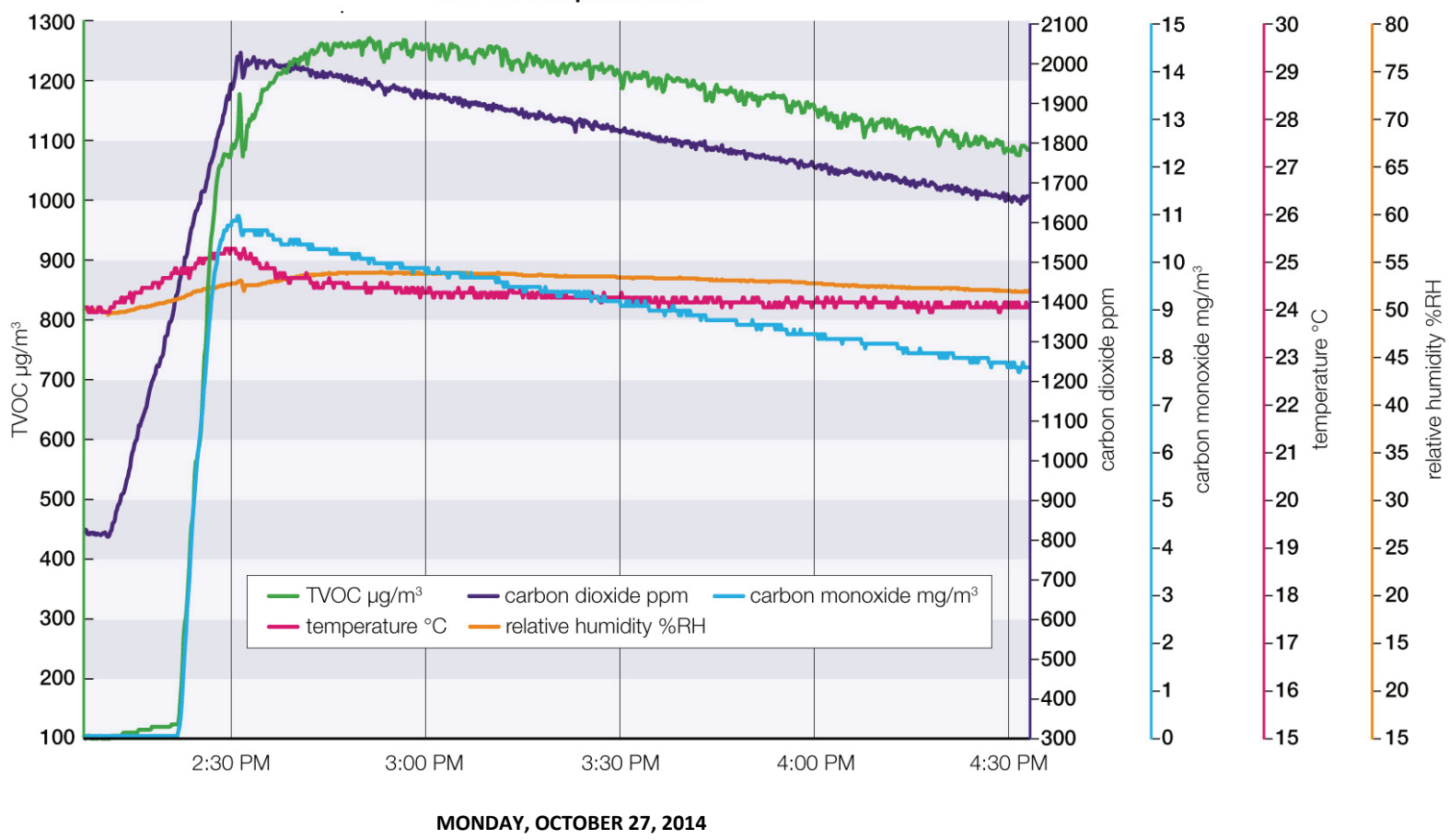

Figure A2. Typical figure of real-time measurement for $\mathrm{CO}, \mathrm{CO}_{2}$, TVOCs, temperature, and relative humidity. 


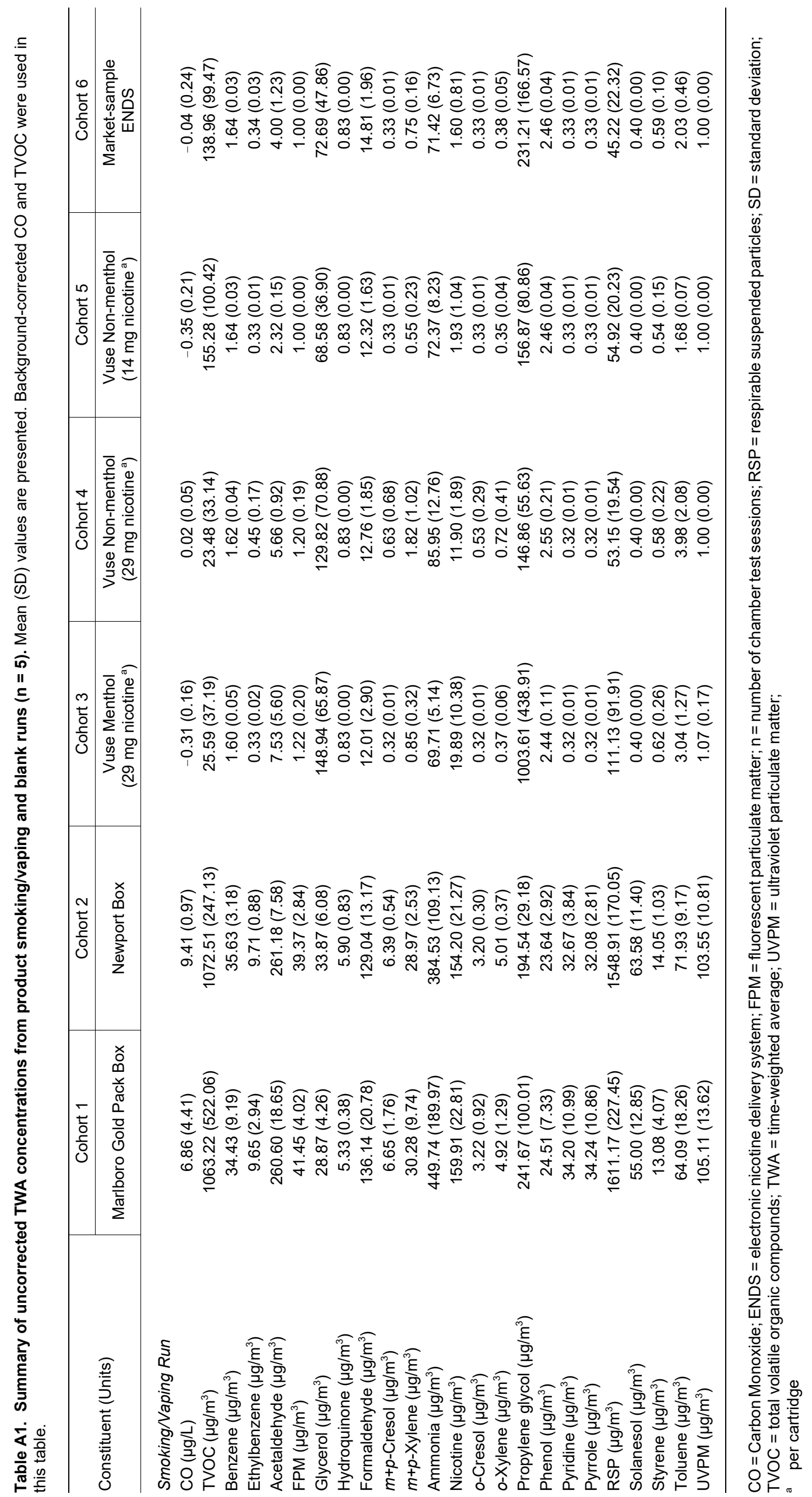




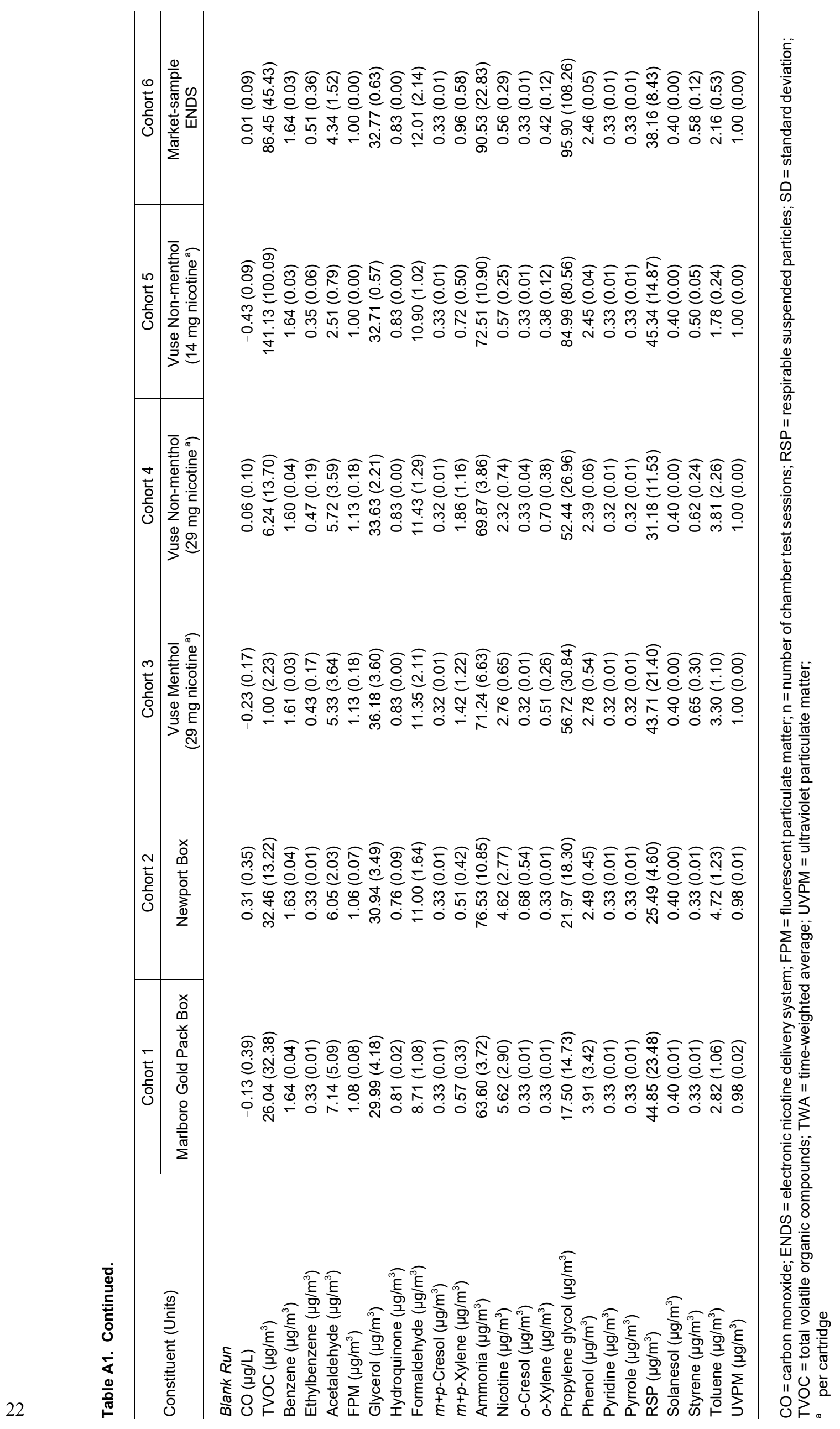




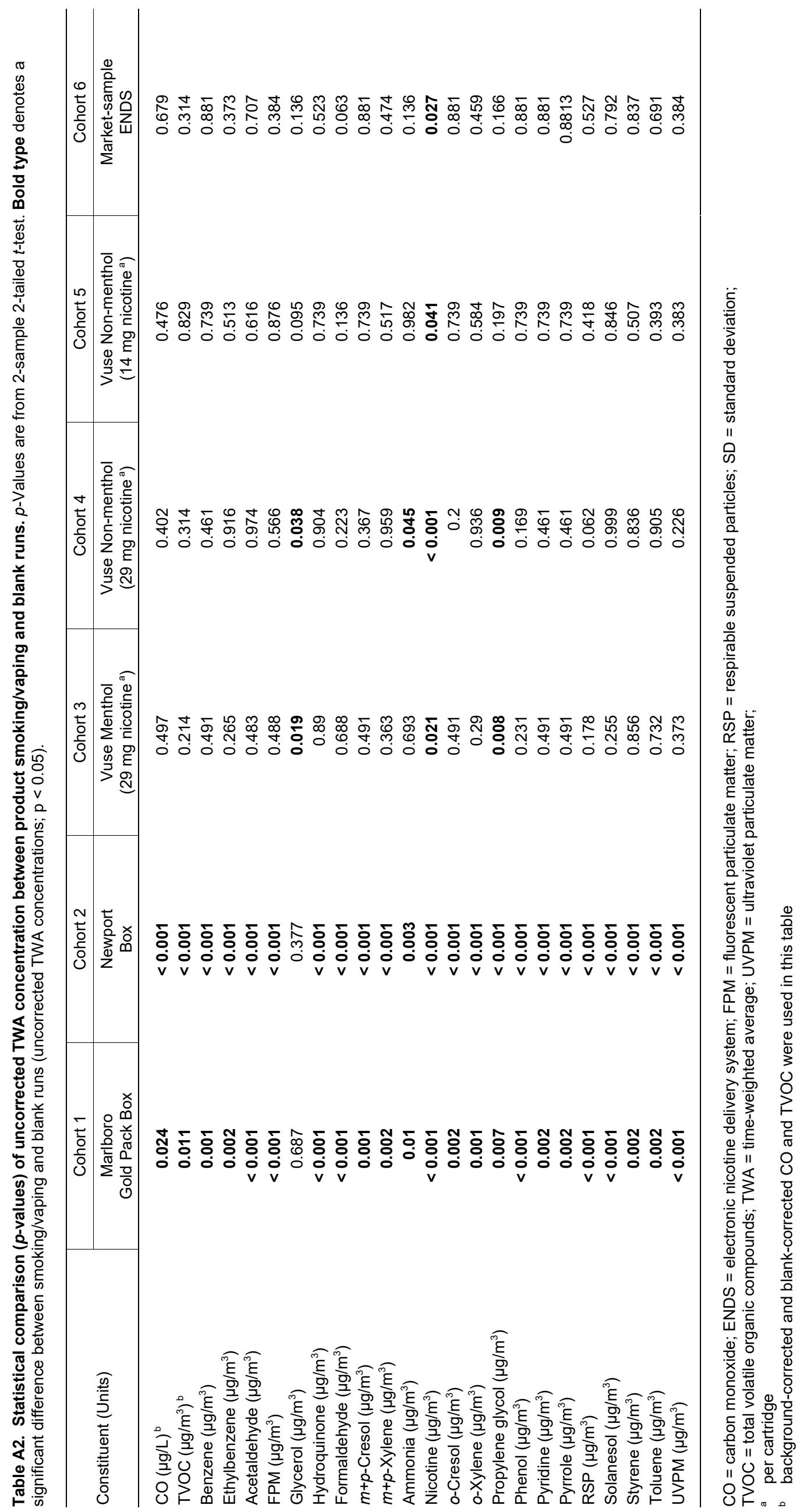


Table A3. Exposure limits for propylene glycol.

\begin{tabular}{llcl}
\hline Country & Type of limit & Reference concentration & Organization (Reference) \\
\hline Germany & Precautionary level & $60 \mu \mathrm{g} / \mathrm{m}^{3}$ & German Federal EPA $^{(48)}$ \\
Germany & Health hazard level & $600 \mu \mathrm{g} / \mathrm{m}^{3}$ & German Federal EPA $^{(48)}$ \\
United States & 30-day TWA limit & $9.5 \mathrm{mg} / \mathrm{m}^{3}$ & NASA $^{(49)}$ \\
United States & WEELs & $10 \mathrm{mg} / \mathrm{m}^{3}$ & AlHA $^{(50)}$ \\
The Netherlands & Occupational exposure limit & $50 \mathrm{mg} / \mathrm{m}^{3}$ & DECOS $^{(51)}$ \\
United States & 24-h TWA limit & $53.8 \mathrm{mg} / \mathrm{m}^{3}$ & NASA $^{(49)}$ \\
\hline
\end{tabular}

* Superscripts correspond to reference number in the bibliography of main paper.

AlHA = American Industrial Hygiene Association; DECOS = Dutch Expert Committee on Occupational Safety;

$\mathrm{EPA}=$ German Federal Environmental Protection Agency; NASA = National Aeronautics and Space Administration;

TWA $=$ time-weighted average; WEELs ${ }^{\circledR}=$ workplace environmental exposure levels 